\title{
Family Ties
}

\section{Citation}

Alesina, Alberto, and Paola Giuliano. 2014. "Family Ties." Handbook of Economic Growth: 177215. doi:10.1016/b978-0-444-53538-2.00004-6.

\section{Published Version}

doi:10.1016/B978-0-444-53538-2.00004-6

\section{Permanent link}

http://nrs.harvard.edu/urn-3:HUL.InstRepos:34330186

\section{Terms of Use}

This article was downloaded from Harvard University's DASH repository, and is made available under the terms and conditions applicable to Open Access Policy Articles, as set forth at http:// nrs.harvard.edu/urn-3:HUL.InstRepos:dash.current.terms-of-use\#OAP

\section{Share Your Story}

The Harvard community has made this article openly available.

Please share how this access benefits you. Submit a story.

Accessibility 


\title{
Family Ties ${ }^{1}$
}

First Draft: March 2013

\author{
Alberto Alesina \\ Harvard University and IGIER Bocconi
}

\section{Paola Giuliano}

UCLA

\begin{abstract}
We study the role of the most primitive institution in society: the family. Its organization and relationship between generations shape values formation, economic outcomes and influences national institutions. We use the World Values Survey to measure the strength of family ties and economic attitudes, controlling for country fixed effects. We study several economic attitudes toward working women, the society, generalized morality and civic engagement. Individuals with strong family ties have more traditional beliefs about the role of women in society, are more reluctant to changes in society and innovation and show a lower level of trust. We also uncover interesting correlations at the country level, where the strength of family ties is associated with lower GDP and lower quality of institutions. These results remain valid if one exploits the correlation between inherited family values and current institutions and level of development, indicating a strong persistence in family values. The quality of family relationships, on the positive side, increases happiness, life satisfaction and self-reported health.
\end{abstract}

JEL Classification: J2, J6, O4, O5, Z1

Keywords: family values, cultural economics, labor market regulations, growth, institutions

\footnotetext{
${ }^{1}$ In preparation for the Handbook of Economic Growth. We thank Andrea Passalacqua for excellent research assistantship.
} 
Authors’ E-mail address: alesina@,fas.harvard.edu; paola.giuliano@anderson.ucla.edu 


\section{Introduction}

Economists, sociologists and political scientists have long been interested in studying the effect of different family structures on a variety of economic outcomes. There is hardly an aspect of a society's life that is not affected by the family.

The aim of this chapter is to review the role that family ties may play in determining fundamental economic attitudes. The importance of the family as a fundamental organizational structure for human society is of course unquestionable. Historical examples of attempts at eliminating the family as an institution have been a catastrophic failure, think of the cultural revolution in China or the Cambodian communism. In this chapter we investigate the effects of different types of family values. In particular, we plan to investigate empirically an idea first developed by political scientists and researchers in the late ' 60 s and early ' 70 s, on the importance of family ties in explaining social capital, political participation and economic outcomes. The family organization can take different forms, with very tight links between members or a more liberal/individualistic structure even within a well structured and organized family. The idea that a culture based on too strong family ties may impede economic development is not new. It goes back at least to Weber (1904), who argues that strong family values do not allow the development of individual forms of entrepreneurship, which are fundamental to the formation of capitalistic societies. Another author who clearly described the relationship between family values and under-development is Banfield (1958). In studying differences between the Southern and Northern part of Italy, this author suggested that "amoral familism" was at the core of the lower level of development of the South. He depicts "amoral familism" as a particular cultural trait: the "inability of the villagers to act together for their common good or, indeed, for any end transcending the immediate, material interest of the nuclear family. This inability 
to concert activity beyond the immediate family arises from an ethos - that of "amoral familism [...] according to which people maximize the material, short run advantage of the nuclear family; and assume that all others will do likewise". This is of course an extreme, and in a sense degenerate, form of family relationship.

This extreme reliance on the family prevents the development of institutions and public organizations, which, on the contrary, require generalized trust and loyalty to the organization. When people are raised to trust their close family members, they are also taught to distrust people outside the family, which impedes the development of formal institutions.

Strong family ties are not unique to the Italian case, but are also present in many Asian and Latin American countries. Fukuyama (1995) for example argues that "though it may seem a stretch to compare Italy with the Confucian culture of Hong-Kong and Taiwan, the nature of social capital is similar in certain respects. In parts of Italy and in the Chinese cases, family bonds tend to be stronger than other kinds of social bonds not based on kinship, while the strength and number of intermediate associations between state and individual has been relatively low, reflecting a pervasive distrust of people outside the family". In a similar vein Putnam (1993) refers to many cases in Asia and Latin America where the safety and welfare of the individuals are provided by the family, legal authority is weak and the law resented.

When family ties are so strong the implications for the economy are pervasive. In this chapter we review the literature on the topic, provide new evidence and explore macroeconomic implications of the effect of family values. We start with within country-analysis. This will allow us to include country fixed effects to isolate the impact of family values from other confounding effects. We analyze the relationship between family values and four different types of societal attitudes that have been shown to be conducive to higher productivity and growth. 
In particular, we look at political participation and political action, measures of generalized morality, attitudes toward women and society, labor market behavior and attitudes toward work. We perform our analysis using the combined six waves of the World Value Survey (WVS), a collection of surveys administered to a representative sample of people in more than 80 countries from 1981 to 2010 . We find that on average familistic values are associated with lower political participation and political action. They are also related to a lower level of trust, more emphasis on job security, less desire for innovation and more traditional attitudes toward working women. On the positive side, family relationships improve well-being as measured by self-reported indicators of happiness and subjective health.

As a second step, we present cross-country evidence linking stronger family ties to economic and institutional outcomes. One obvious limitation of this evidence is that family values may be an outcome rather than a driver of economic development. While we do not offer any definite answer to the question of causality, we do show that family values are quite stable over time and could be among the drivers of institutional differences and level of development across countries: family values inherited by children of immigrants whose forebears arrived in various European countries before 1940 are related to a lower quality of institutions and lower level of development today. We also show that the relationship between economic and institutional outcomes is fairly robust even after controlling for legal origin, which has been shown to be an important historical determinant of formal institutions across countries.

The chapter is organized as follows. In Section 2, we review the literature on family ties. In Section 3 we provide a logical framework for the empirical analysis, linking our paper to the theoretical models analyzing the impact of culture on economic outcomes. In Sections 4 and 5, we describe how family ties and family 
structures can be measured and review the deep historical determinants of family ties. Sections 6 presents results from the within country analysis. Section 7 presents cross-country evidence linking stronger family ties to economic development and institutions and also show the persistence of family values and their effect on institutions and development today. Section 8 analyzes the impact of family ties on different measures of well-being and Section 9 concludes.

\section{Literature Review}

There is surprisingly little systematic empirical evidence in economics on the role played by different types of family values in determining either economic outcomes or attitudes which, in turn, have an influence over economic development. Most of the research in economics indeed focused its attention on institutions, such as political systems (Acemoglu, Johnson and Robinson, 2001 and 2005), the legal rights of the individual (North, 1990), religion (Guiso, Sapienza and Zingales, 2006), education (Glaeser, Ponzetto and Shleifer, 2007), social capital (Putnam, 1993 and 2000), ethnic fractionalization (Easterly and Levine (1997) and Alesina and La Ferrara (2005) for a survey) to explain a society's ability to generate innovation, wealth and growth. Yet, little attention has been devoted to the most primitive societal institution, the family, and how this could be relevant in explaining a variety of socio-economic outcomes.

The work on the relevance of the family starts with Banfield (1958) and Coleman (1990). Both authors notice that societies based on strong ties among family members, tend to promote codes of good conduct within small circles of related persons (family or kin); in these societies selfish behavior is considered acceptable outside the small network. On the contrary, societies based on weak ties, promote good conduct outside the small family/kin network, giving the possibility to identify oneself with a society of abstract individuals or abstract institutions. 
This initial intuition has been confirmed recently in an experimental setting by Enrich and Gambetta (2010). The authors use a trust game, played by a representative sample of the British population, and find that people with strong family ties have a lower level of trust in strangers than people with weak family ties.

After the seminal contribution of Banfield (1958) and Coleman (1990), some academics have noted strong patterns of family structures and linked them to significant social and economic outcomes. This includes work by Todd (1985 and 1990), Greif (2005, 2006) and Greif and Tabellini (2012). Using data on family structures dating back to the Middle ages, if not earlier, Todd focuses on the distinction between nuclear and extended family. These two family structures differ in the degree of cooperation between subsequent generations, and in the authority exercised by parents. At one extreme, nuclear families are those in which children are emancipated from their parents and leave the household at the time of marriage or before. At the opposite extreme, the extended family typically consists of three generations living together and mutually cooperating under patriarchal authority.

Todd measures the diffusion of both family types across Western Europe and uses this distinction to explain relative levels of diffusion or resistance to important societal changes such as Protestantism, secularism or political ideology. His general idea is that the nuclear family's tradition of emancipation increases potential for movement away from the family home which can facilitate the pursuit of independent economic opportunities. Also, the inability to rely on the family for income and housing could be said to generate a more entrepreneurial spirit of selfreliance as well as greater motivation to work. Todd's (1990) definition of family structures has been used more recently (Duranton et al. 2009) to explain contemporary outcomes of European regions. The authors identify important links 
between family types and regional disparities in household size, educational attainment, social capital, labor force participation, sectoral structure, wealth and inequality.

Greif (2005) focuses its attention on the distinctions between nuclear families and large kinship groups. Similarly to Todd, he emphasizes the sense of independence coming from nuclear family structures. In particular, he describes how nuclear families in medieval times facilitated the establishment and growth of corporations: "an individual stands to gain less from belonging to a large kinship group, while the nuclear family structure increases its gains from membership in such a corporation (Greif 2005: 1-2)". Greif presents a feedback effect where causation works in both directions - on the one hand, nuclear families facilitate the establishment of corporations; on the other the economic and social transformation related to the development of corporations, encourage the domination of the nuclear family across Europe. Greif's idea is that nuclear families encourage both flexibility and independence; corporations have the goal of substituting for kinship groups and provide safety net, therefore complementing the nuclear family. Greif and Tabellini (2012) distinguish two different modes of sustaining cooperation in China and Europe. In China, the clan (a common descent group consisting of families tracing their patrilineal descent back to one common ancestor who settled in a given locality) was the fundamental institution, which had prevailed for more than 800 year, beginning with the Song Dynasty. Clan-based organizations provided public goods and social safety nets. In Europe, where the nuclear family was more prevalent, the locus of cooperation became the city, whose members were drawn from many kinship groups. The authors show that in a clan, moral obligations are stronger but are limited in scope, as they apply only toward the kin. In a city, moral obligations are generalized towards all citizens irrespective of lineage, but they are weaker. They refer to this distinction as limited versus 
generalized morality, which is strongly correlated in our paper to the strength of family ties today. The authors show that the prevalence of one or the other organizational form depends on the distribution of values in society. Like Greif (2005), they recognize the existence of a feedback effect: subsequent social, legal and institutional developments evolved in different directions in these two parts of the world, strengthening the clan in China and leading to the emergence of strong and self-governed cities in Europe. The authors interestingly exploit differences in the early family structures across different parts of Europe, taking family structures as indicators of the scope and strength of kin-based relations. As expected, historical patterns of urbanization within Europe reflect these different family traditions, with early urbanization being much more diffused in the European regions, where families with weaker ties were more prevalent.

Alesina and Giuliano (2010) analyze systematically the role of the family as primal institution in a society, showing that the strength of family ties represents a fundamental trait shaping economic behavior and attitudes. Contrary to Greif (2005) and Todd (1985 and 1990), the authors do not distinguish between nuclear and extended families, but construct a subjective variable on the strength of family ties using three different questions from the World Value Survey regarding the importance of the family, the love and respect that children are expected to have for their parents, and the parental duties toward their children ${ }^{2}$. Alesina and Giuliano (2010) show that strong family ties are correlated with a larger amount of home production, lower labor force participation of women and young adult, and lower geographical mobility. In a companion paper (Alesina and Giuliano, 2011), the authors also establish an inverse relationship between family ties, generalized trust and political participation. Strength and weakness of family ties, defined as

\footnotetext{
${ }^{2}$ In section 4, we show that there is indeed a strong correlation across countries between nuclear and extended family and family ties as measured by subjective measures taken from the World Values Survey. Alesina et al. (2013) also show that subjective measures of strong family ties are correlated with Todd's definition of extended families at the regional level, at least for the case of Europe.
} 
"cultural patterns of family loyalties, allegiances and authorities" also help explaining living arrangements and geographical mobility of young generations (Reher, 1998; Giuliano, 2007), larger fractions of family firms across countries (Bertrand and Shoar, 2006) and cross-country heterogeneity in employment rates (Algan and Cahuc, 2007).

While all the above mentioned papers take the strength of family values as given and persistent, Alesina et al. (2013) go one step further and explore the presence of a feedback effect between family ties and labor market institutions. This paper is particularly relevant because it looks at the co-evolution of culture and institutions leading to multiple equilibria. The main idea of the paper is that in cultures with strong family ties individuals are less mobile and prefer more regulated labor markets while weak family ties are associated with more flexible labor markets, which then require higher geographic mobility of workers to be efficient. In this setup, individuals inherit strong or weak family ties with a certain probability. Strong family ties provide a certain utility to each individual, which is larger the larger is the share of individuals with strong family ties in a society. Given their utility function, individuals vote with majority rule on labor market regulation. There are two types of labor market policies: labor market flexibility (i.e. laissez-faire) or regulation of wages and employment. Individuals with weak family ties have a higher utility under flexibility, so this regime is voted if the society starts from a situation in which the majority of the population has weak family ties. On the other hand, the utility of individuals with strong family ties is always higher under regulation. Finally firms offer labor contract. The assumptions in the model are such that a worker with weak family ties always find a job equal where he/she is paid for his/her productivity since he/she has no mobility cost. A worker with strong family ties has a moving cost related to the disutility to live far away from his/her family. Labor market regulations are precisely put in place to 
protect those workers from the monopsony power of firms. The model implies two stable Nash equilibria. One, where everybody chooses weak family ties and then votes for labor market flexibility. In this case, labor market is competitive, everyone is paid his marginal productivity and labor mobility is high. The other, where everyone chooses strong family ties and then votes for stringent labor market regulation. In this case the labor market is monopsonistic because workers are immobile. This is the reason why people vote for stringent labor market regulation.

The model is able to explain the correlation between labor market regulation and family ties, and also has a number of implications which are tested using various surveys. In particular, the authors investigate the correlation between family values and attitudes toward labor market regulation and preferences for job security with cross country evidence and individual evidence drawn from children of immigrants in the US. Although the theoretical model points to the possibility of a feedback effect between labor market regulations and family ties, the empirical part of the paper presents suggestive evidence that the correlation is more likely to run from cultural values to institutions. The authors present two sets of evidence to make this point. First they show a strong correlation between family structures today and family structures in the Middle Ages. As a second step, the authors show that family values inherited by immigrants arrived to the US prior to 1940 are correlated to labor market institutions created after WWII.

On the relationship between family and institutions, the link between family relations and welfare systems has received a recent attention, mainly by sociologists. Focusing on Europe, Esping-Andersen (1999) argues that citizens obtain welfare from three basic sources: markets, family and government. Where family ties are stronger, social risks are more internalized in the family by pooling resources across generations. His idea is that differences in family relations were at 
the core of the different evolutions of welfare systems, observed after WWII. In particular he distinguishes three different types of welfare states: the liberal welfare state (typical of countries like the US), this is a regime that favors small public intervention under the assumption that the majority of citizens can obtain adequate welfare from the market. The second example is the social-democratic regime, characterized by its emphasis on universal inclusion and its comprehensive definition of social entitlements. This model, typical of the Nordic European countries, is internationally unique in its emphasis on de-familizing welfare responsibilities, especially with regard to care for children and the elderly. The third, and somewhat more heterogeneous, regime embraces the majority of Continental European countries, Austria, Belgium, France, Germany, Italy and Spain. This regime is strongly familistic, assuming that primary welfare responsibilities lie with family members.

Coleman $(1988,1990)$ also stresses the mutual insurance mechanisms provided by old and young generations in familistic societies. He argues that family ties can strengthen the support received by young generations from the old while, at the same time, representing an obstacle for innovation and new ideas. Finally, Galasso and Profeta (2012) show that the strength of family ties is related to the type of pension system chosen by a country. Societies dominated by absolute nuclear families (or weak family ties, such as for example the Anglo-saxon countries) facilitate the emergence of a pension system which acts as a flat safety net entailing the largest within-cohort redistribution than societies dominated by any other type of family.

\section{Conceptual Framework}

Many authors have stressed the relevance of the historical origins of (under)development (North, 1981, Acemoglu, Johnson and Robinson, 2001) but a 
still unanswered question is how differences in historical experiences are perpetuated till today. A recent strand of literature focuses on the importance of normative individual values to explain this persistence. One reason for why individual values can be relevant is the observation that very often, inside the same country, similar institutions work in a very different way. Putnam (1983) used the example of Italy. He pointed out that for distant historical reasons local governments, courts, schools and even the private sector are much less efficient in the South than in the North of Italy despite the presence of national institutions. Guiso, Sapienza and Zingales (2008) recently pushed forward Putnam's analysis confirming his basic intuition. The authors show that inhabitants of Italian cities that had the status of free city-states at the beginning of the first millennium, where citizens were deeply involved in political life, today also have a higher level of social and civic capital, as measured by participation in elections and a variety of associations, and a higher level of blood donation.

There are different values that can be relevant to explain the sources of underdevelopment in a country. In this chapter we explore the idea that trust restricted only to family members prevents the formation of generalized trust, which is at the core of many collective good outcomes, from political participation to the formation of institutions to economic outcomes (Banfield (1958), Gambetta (1988), Putnam (1993), Fukuyama (1995) and Coleman (1988, 1990). ${ }^{3}$ Also the organization of the family as a strong "production unit" implies certain views about living arrangements and the role of women in market activities versus home production.

This paper is part of a rapidly growing literature that has emphasized the relevance of specific cultural traits for economic and political outcomes. Akerlof and Kranton (2010), Alesina et al. (2013), Guiso, Sapienza and Zingales (2006),

\footnotetext{
${ }^{3}$ Tabellini (2010) provide an excellent formalization of these ideas.
} 
Fernandez and Fogli (2009), Gorodnichenko and Roland (2013), Spolaore and Wacziarg (2009), Tabellini (2008, 2010) all provide extensive references and illustrate different applications of this new line of research.

The basic idea underlying the empirical analysis of this chapter is that these normative values evolve slowly over time, as they are largely shaped by values and beliefs inherited from previous generations. In particular, a culture of familism, defined as individual values that stress the link between parents and children and loyalty to the family is an important channel through which distant history can explain the functioning of current institutions and economic development. We explore this idea in two steps, we first use within country analysis to study the effect of family values on other types of economic attitudes, which are relevant for growth. Although the issue of reverse causality is an important one, we use established evidence that family values today are related to the ancient family structures (see Alesina et al. (2013), Duranton (2009), Galasso and Profeta (2012) and Todd (1990)). As a second step, we discuss aggregate evidence looking at differences in institutions and economic outcomes between weak and strong family ties societies. The correlations shown are strong and consistent with the microeconomic data. Altogether they suggest that well functioning institutions and development are often observed in countries or regions where individuals have weak family ties.

Before looking at the empirical evidence, we provide a logical framework for why cultural traits in general and family values in particular are relevant. The economics literature has used the word culture with different meanings. According to one definition culture refers to the social conventions and individual beliefs that sustain Nash equilibria as focal points in repeated social interactions (Greif 1994). In more recent contributions, individuals' beliefs are initially acquired through cultural transmission and then slowly updated through experience from one 
generation to the next. This line of argument has been pursued by Guiso, Sapienza and Zingales (2010) who build an overlapping generation model in which children absorb their trust priors from their parents and then, after experiencing the real world, transmit their (updated) beliefs to their own children. An alternative interpretation is that culture refers to more primitive objects, such as individual values and preferences (Akerlof and Kranton, 2000). This latter interpretation is consistent with an emerging literature in psychology, sociology and evolutionary biology that emphasizes the role of moral emotions in motivating human behavior and regulating social interactions.

Following broadly this last approach, we view cultural beliefs as decisionmaking heuristics or "rules-of-thumb" that are employed in uncertain or complex environment. Boyd and Richerson (1985) show that if information acquisition is either costly or imperfect, it can be optimal for individuals to develop heuristics or rules-of-thumb in decision-making. By relying on general beliefs about the right thing to do in different situations, individuals may not behave in a manner that is precisely optimal in every instance, but they save on the costs of obtaining the information necessary to always behave optimally. In practice, these heuristics often take the form of deeply held traditional values or religious beliefs (Gigerenzer 2007, Kahneman 2011).

The concept of culture as moral principles, rules of thumb or normative values that motivate individuals is particularly appealing. Whereas social conventions sometimes change suddenly because of strategic complementarities, and beliefs are updated as one learns from experience or from others, individual values or rules of thumbs are likely to be more persistent and to change slowly from one generation to the next. The reason is not only that normative values are acquired early in life and become part of one's personality but also that learning from experience cannot logically be exploited to easily modify them. Thus, values 
are likely to be transmitted vertically from one generation to the next, to a large degree within the family, rather than horizontally across unrelated individuals, and also persist over time.

There are a number of reasons why we may observe persistence. First, the underlying cultural traits maybe reinforced by policies, laws and institutions, which reinforce the beliefs. A society with familistic values may perpetuate these beliefs by institutionalizing different forms of welfare state, different maternal leave policies, different pension systems. Another source of persistence can arise from a complementarity between cultural beliefs and industrial structure. Beliefs on the importance of the family may cause a society to specialize in family based industries, which reinforce the attachment to the family, therefore perpetuating this trait. A third explanation that does not rely on these forms of complementarity is that cultural beliefs, by definition, are inherently sticky. The benefit of decisionmaking rules-of-thumb is that they can be applied widely in a number of environments, saving on the need to acquire and process information with each decision.

Empirically, several studies have investigated the persistence of cultural traits by looking at subnational analysis, therefore holding constant industrial structure, domestic policies and institutions. More directly, looking at children of immigrants, the literature has held constant the external environment. We follow this tradition. In particular, we use within country analysis to hold constant the presence of institutions and policies. The concern of reverse causality is limited by the fact that in literature it has been shown that values toward the family today are related to historical family structures (see Alesina et al. (2013) and Galasso and Profeta (2012)). Another part of the literature has also shown that many of the outcomes reviewed in this chapter tend to persist among second generation 
immigrants in the US and other countries as a result of different values regarding the strength of family ties (Alesina and Giuliano (2010) and Alesina et al. (2013).

\section{How to measure family ties}

In this section we describe different ways of measuring family ties using existing datasets. In particular we describe a measure of family ties using individual responses from the World Value Survey (the measure used for the empirical analysis of this chapter) and one based on the classification by Emmanuel Todd $(1983,1990)$.

\subsection{Measuring family ties using the World Values Survey}

One possible way to measure family ties is to use data from the World Value Survey (WVS). The WVS is a cross-country project carried out for more than twenty years. Each wave carries out representative national surveys of the basic values and beliefs of individuals in a large cross-section of countries. The questionnaires contain information about demographics (sex, age, education), selfreported economic characteristics (income, social class) and answers to specific questions about religion, political preferences and attitudes. Alesina and Giuliano (2010) measure the strength of family ties by looking at three WVS variables capturing beliefs on the importance of the family in an individual's life, the duties and responsibilities of parents and children and the love and respect for one's own parents. The first question assesses how important the family is in one person's life and can take values from 1 to 4 (with four being very important and 1 not important at all). The second question asks whether the respondent agrees with one of two statements (taking the values of 1 and 2 respectively): (1) one does not have the duty to respect and love parents who have not earned it; (2) regardless of what the qualities and faults of one's parents are, one must always love and respect them. The third question prompts respondents to agree with one of the following 
statements (again taking the values of 1 or 2 respectively): (1) Parents have a life of their own and should not be asked to sacrifice their own well being for the sake of their children; (2) it is the parents' duty to do their best for their children even at the expense of their own well being. The questions can be combined by extracting the first principal component from the whole dataset with all individual responses for the original variables.

Table 1 displays the correlation at the country level between the three original measures and the first principal component. All the variables are highly and positively correlated amongst each other. Figures 1-4 show map of each single question and the first principal and Figure 5 displays the values of the measure of the strength of family ties (expressed using the first principal component) at the country level ${ }^{4}$. The ranking generally reflects priors of the sociological literature. Scandinavian countries and many Eastern European countries tend to have the weakest levels of family ties. In a middle range are France, Canada, the United States and the United Kingdom. More familistic societies are Italy and many Latin American countries including Colombia, Peru and Brazil. In the extreme part of the distributions are some Latin America countries like Guatemala and Venezuela, African countries like Egypt and Zimbabwe and Asian countries like Indonesia, Vietnam and the Philippines.

The strength of family ties varies not only across countries, but also across regions belonging to the same country. Figure 6 represents the partial correlation of the relationship between generalized trust and the strength of family ties for the case of Europe, after controlling for country fixed effects. As it is apparent from the figure, even after controlling for country characteristics, the variation in family ties across Europe is sufficient to explain differences in social capital inside Europe. The difference in the strength of family ties inside the same country can be

${ }^{4}$ The measure is calculated using the six waves from the WVS. 
very pronounced. In Italy the lowest level of family ties is observed in Valle D'Aosta (where it is equal to -0.22 , a level similar to some of the Swedish regions), the highest in Calabria (where it reaches the value of 0.44).

\subsection{Todd's classification of family structures}

In his books, The invention of Europe (1990) and The Explanation of ideology: Family Structures and Social Systems (1983), Emmanuel Todd classifies family structures according to two main organizing principles. The first principle concerns the vertical relationship between parents and children. The family is defined as "authoritarian" if children are subject to the parental authority even after marriage. The family is defined as "liberal" if children become independent from the parental authority by leaving the parental nest in early adulthood. To measure authoritarian versus liberal families, Todd (1990) looked at data on cohabitation between generations within families, in particular between parents and their married children. The family is authoritarian if the eldest son stays in the family when he marries and remains under the authority of the father. Unmarried daughters remain in the family home under the authority of the father or their brothers, when the father dies. In the "liberal" case, children leave the parental home when they reach adulthood or after marriage.

The second organizing principle concerns the relationship between siblings. The family is defined as "equal" if all siblings are treated equally; it is defined as "unequal" if one particular child (most often the eldest) has a priviledged treatment. To measure equality Todd uses data on inheritance laws and practices. A family is equal when family property is divided evenly between siblings and unequal if primo-geniture (or in some cases ultimogeniture) exists. The information on the type of families for both the vertical and the horizontal dimension is obtained by censuses and historical monographs that go back more than 500 years. 
The combination of the authoritarian/liberal vertical relationship with the equal/unequal horizontal relationship give rise to four types of family (depicted in Figure 7):

- Absolute nuclear family: this family type is characterized by indipendent living arrangements (children leave their family in early adulthood either before marriage or to form their own family) and lack of stringent inheritance rules. In this type of family, parents have no obligation to support their adult children; every person is independent and has to rely on his/her individual effort. The United States, the UK, Australia, New Zealand, the Netherlands and Denmark belong to this group. Interestingly, Laslett (1983) has shows that this family characteristics makes young adult free to take residence where job opportunities are best and thus has favoured industrial development.

- Egalitarian nuclear family: this family type is characterized by indipendent living arrangements, like in the absolute nuclear family. The presence of egalitarian inheritance rules, however, encourage the persistence of a strong relationship between parents and children, who are inclined to stay at their parents place longer. To this group belong the Southern European countries (Italy, Spain, Greece and Portugal), Romania, Poland, Latin America and Ethiopia.

- Stem or authoritarian family: this family type is characterized by the cohabitation of parents and children. Inheritance rules are also not egalitarian. Countries belonging to this group are Austria, Germany, Sweden, Norway, Czech Republic, Belgium, Luxembourg, Ireland, Japan, Korea and Israel.

- Communitarian family: this type of family is characterized by cohabitation of parents and children and equal inheritance rules. This 
system characterize countries like Russia, Bulgaria, Finland, Hungary, Albania, China, Vietnam, Cuba, Indonesia and India ${ }^{5}$.

Galasso and Profeta (2012) compare Todd's classification of family structure with the one used in this chapter and also in Alesina and Giuliano (2010). In particular, they use the three different measures of family values described above and compare it with Todd's classification by running the following model:

$$
\begin{gathered}
y_{i}=\alpha+\beta_{1} X_{i}+\beta_{2} \text { Communitarian }_{i}+\beta_{3} \text { Authoritarian }_{i} \\
+\beta_{4} \text { nuclear_egalitarian }_{i}+\varepsilon_{i}
\end{gathered}
$$

where $y_{i}$ is the answer from the WVS to each of the three family measures, $X_{i}$ is a set of individual controls (a quadratic in age, income, education, political views). They include dummies for the prevalent type of family in a country, where the absolute nuclear family is the excluded category. Table 2 reports the results of their specification. Todd's classification plays no role in explaining the answer to the most general question on the important of the family (column 1). However, strong children-to-parents links are associated with communitarian and egalitarian nuclear families (column 2). Finally, authoritarian and communitarian families are associated with a prominent role of parents in today's societies. The authors conclude that current survey data broadly confirm the historical types present in Todd's analysis.

\section{Where family ties are coming from}

A large literature in anthropology has documented that the type of family is related to ecological features and means of subsistence in ancient times (Murdock,

\footnotetext{
${ }^{5}$ Note that Todd (1990) provide regional variations for most European countries, for example the communitarian family was present in the center of Italy. Here we just report the data at the country level. The family type at the country level is based on the type of family present in the majority of the population. For more details on the regional
} 
1949). Typically agricultural societies are characterized by large extended families; whereas the small nuclear family is more prevalent among small hunting and gathering societies. The reason for that is that farming requires the help of many people, usually children and kin, who cooperate to cultivate crops. Studies have found that children in agricultural and pastoral societies are taught to be responsible, compliant, obedient, and to respect the elderly and the hierarchy. Hunting or gathering as a mean of subsistence, on the other hand, requires moving from area to area. Many hunting and gathering societies do not have a permanent home, but temporary huts or shelters. Mobility means that the small nuclear family is more adaptable for survival under these ecological restraints. Children in hunting and gathering societies tend to be self-reliant, independent, and achievement oriented and the family is less stratified.

There is no formal test of whether these ecological features from the distant past tend to persist to the modern times, after industrialization has taken place in many societies. The only work which has studied the correlation between current measures of family ties and long term historical characteristics is Durante (2010). His intuition is fairly close to the anthropological literature. In particular he proposes a simple explanation of the emergence of trust and different forms of family structures based on the need of subsistence farmers to cope with weather fluctuations. A more variable environment should increase an individual's propensity to interact with non-family members and reduce their dependence on the family for insurance purposes. Durante (2010) tests his prediction in the context of Europe, combining high-resolution climate data for the period 15002000 with contemporary survey data on family ties as measured in Alesina and Giuliano (2010) and also generalized trust, using the negative expected relationship between these two variables. He finds that regions with greater inter-annual fluctuations in temperature and precipitation have higher levels of interpersonal 
trust and weaker family ties. This result is primarily driven by weather variability in the growing-season months, consistent with the effect of climatic risk operating primarily through agriculture. He then replicates the analysis using climate data for the period 1500-1750. The relationship between historical climatic variability and trust and weak family ties is positive and significant, even after controlling for climate variability between 1900-2000, which does not appear to have an independent effect on trust or family ties. These findings support an explanation based on the historical formation and long-term persistence of trust and family attitudes. The results of Durante's specifications are reported in Table 3.

\section{Empirical analysis}

To examine the relationship between family values and economic attitudes, we use within country analysis drawn from the WVS. Our measure of family ties is defined as the principal component of three subjective measures regarding the role of the family, and the link between parents and children, as described in Section 4.1. We use all available six waves, therefore providing the most comprehensive analysis of the impact of family values on a variety of attitudes ${ }^{6}$. The coverage of countries varies across surveys. The 1981-1984 survey covered 24 countries; the 1989-1993 wave covers 43 countries; the 1994-1999, 1999-2004, the 2005-2007 and 2008-2010 cover respectively 54, 70, 57 and 47 countries.

The use of within country analysis allows us to control for country fixed effects, eliminating the impact of other institutional variables. This approach underestimates the effect of family ties, to the extent that in the distant past they had an impact on current institutions. Nevertheless, the effect can be attributed more credibly to this cultural trait. Omitted variables ad reverse causality can still be a problem for this type of regressions, for this reason we prefer to interpret our

\footnotetext{
${ }^{6}$ Alesina and Giuliano (2010) only used four waves, having a substantially smaller sample size.
} 
results as more precisely estimated partial correlations. We divide our dependent variables into five groups.

\subsubsection{Measures of interest in politics and political action}

We begin with measures of people's interest in politics and political action. The first variable, which we label interest in politics, is based on the following question "How interested would you say you are in politics?", the response varies from 1 (not at all interested) to 4 (very interested). Variable 2, which we label discuss politics, asks the respondent "How often discusses political matters with friends", with the answer going from never (1), occasionally (2) to frequently (3). Variables 3 and 4 measure if the respondent belongs to political parties (the first question measures it with a dummy if the person belongs to a political party and zero otherwise; the second question can take values from 0 to 2 , with 0 (not a member), 1 (inactive member) and 2 (active member). The last five questions measure different forms of political action, asking the respondent whether he/she has actually done any of these things (taking the value of 3), whether he/she might do it (2) or whether he/she would never do it (1): signing a petition, joining in boycotts, attending lawful/peaceful demonstrations, joining unofficial strikes, occupying buildings or factories.

Understanding the origin of civic culture and of a well educated population is an important prerequisite to a well-functioning and stable democracy (Lipset (1959), Almond and Verba (1963), Glaeser et al. (2004), Glaeser et al. (2007), Persson and Tabellini (2009)).

\subsubsection{Measures of generalized morality and attitudes toward society}

The second group of questions contains two measures of generalized morality (related to a definition by Tabellini (2008), explained below), one question about trust in the family and three questions about attitudes towards 
society. Variable one, trust, is based on the following question: "Generally speaking, would you say that most people can be trusted or that you can't be too careful in dealing with people?", the variable is equal to 1 if participants report that most people can be trusted and zero otherwise. Variable 2 asks whether obedience is a quality that children can be encouraged to learn at home, taking the value of 1 if the quality is mentioned and 0 otherwise. Variable 3 asks how much the respondent trusts the family from "do not trust the family at all" (1), "do not trust the family very much" (2), "neither trust nor distrust the family" (3), "trust the family a little" (4), "trust the family completely" (5). The last three questions refer to attitudes about the possibility of changing society. The first question asks on a scale from 1 to 10 whether "Ideas that stood test of time are generally best" (taking the value of 1) or whether "New ideas are generally better than old ones"; the second question asks if "One should be cautious about making major changes in life" (taking the value of 1) versus "You will never achieve much unless you act boldly" (taking the value of 10). The third questions asks the respondent to choose between three basic kinds of attitudes concerning society: "society must be valiantly defended" (taking the value of 1), "society must be gradually improved by reforms" (taking the value of 2) and "society must be radically changed" (taking the value of 3 ).

Amongst all the above variables "trust" measures a fundamental trait in a society. More than 35 years ago Kenneth Arrow (1972), recognizing the pervasiveness of mutual trust in commercial and non-commercial transactions, went so far as to state that "it can be plausibly argued that much of the economic backwardness in the world can be explained by the lack of mutual confidence "( $p$. 357). Since then, Arrow's conjecture has received considerable empirical support. A vast literature investigates the link between aggregate trust and aggregate economic performance, trust also encourage welfare enhancing social interactions, 
such as anonymous exchange of participation in the provision of public goods, and they are likely to improve the functioning of government institutions. Starting with Banfield, it has also been postulated a negative correlation between trust in a small related circle (like the family) and generalized trust. Platteau (2000) links lack of generalized trust to the distinction between "generalized" versus "limited" morality. In hierarchical societies, trust and honest behavior are often confined to small circles of related people (like members of the family). Outside of this small network, opportunistic and highly selfish behavior is regarded as natural and morally acceptable. These two measures have been defined to distinguish between values consistent with "generalized" vs "limited" morality. Tabellini (2008) has shown that generalize morality is fundamental to understand the origin of economic development across countries and also among regions of Europe. We therefore look at the relevance of family ties in the formation of generalized trust and trust toward the family (expecting a negative impact of family ties on generalized trust and a positive impact on trust in the family). In strong family ties societies, individualism is also mistrusted. In familistic societies, the role of parents is to foster obedience. Banfield emphasized the relevance of obedience to claim that such coercive cultural environment reduces individual initiative and cooperation within a group and can hurt growth and development.

The last three questions are related to Coleman's idea (1988) that family ties can represent an obstacle for innovation and new ideas.

\subsubsection{Labor market and attitudes toward work}

The third group of questions looks at the relationship between family values and the labor market. We explore the correlation between female, youth and elderly labor force participation and family ties. We also look at questions regarding the relationship between job security and family ties. One question asks the respondent how important is job security in a job. In another one, the 
respondent has to choose the most important thing in looking for a job, where a safe job with no risk is one of five choices (the other four including a good income, working with people one likes, doing an important job, do something for the community).

Employment rates vary dramatically across countries, but the bulk of the variation relies on specific demographic groups: women, younger and older individuals. Looking at micro and macro data for OECD countries, Algan and Cahuc (2007) show that differences in family culture can explain lower female employment and also lower level of employment of young and older people in Europe $^{7}$. In the same fashion, Giavazzi, Schiantarelli and Serafinelli (2013) find that culture matters for women employment rates and for hours worked. In a recent paper, Alesina et al. (2013) look at the relationship between family ties and the labor market. The main idea is that in cultures with strong family ties, moving away from home is costly. Thus individuals with strong family ties choose regulated labor markets to avoid moving and limiting the monopsony power of firms, even though regulation generates lower employment and income. We look at within country analysis on preferences for job security that further limit the possibility that the results are driven by other country characteristics.

\subsubsection{Measures of attitudes toward women}

The fourth group of variables contains measure of people's attitude toward women. The first question asks the respondent whether he/she agrees with the statement "When jobs are scarce, men should have more right to a job than women". The other six variables come from the answer to the question "For each of the following statements I read out, can you tell me how much you agree with

\footnotetext{
${ }^{7}$ Although the authors attribute the differences in employment rates to the presence of the nuclear versus the extended family in different OECD countries, the effect on employment is not studied using different family structures but considering some subjective measures. In particular they look at three questions: one asking the respondent whether he/she agrees with the statement that "when job are scarce, older people should be forced to retire from work early", the second asking the respondent whether they agree with the statement that "Adult children have a duty to look after their elderly parents" and finally a third question asking whether independence is a quality that children should be encouraged to learn at home.
} 
each. Do you agree strongly, agree, disagree, or disagree strongly". The statements are: "A working mother can establish just as warm and secure a relationship with her children as a mother who does not work", "Being a housewife is just as fulfilling as working for pay", "On the whole, men make better political leaders than women do", "A university education is more important for a boy than for a girl", "A pre-school child is likely to suffer if his or her mother works", "A job is alright but what most women really want is a home and children". We recode the questions so that a higher number means a more traditional perception of the role of women in society.

Gender role attitudes are relevant in explaining differences in female labor force participation across countries (see Fortin and Fernandez and Fogli (2009)). In strong family ties societies (Esping-Andersen 1999; Ferrera 1996; Castles 1995; Korpi 2000), family solidarity is based on an unequal division of family work between men and women (what has been called the "male-breadwinner hypothesis"): weak family ties will foster an egalitarian gender role in which men and women participate equally in employment and housework, whereas strong family ties are based on the "male-breadwinner hypothesis" in which men work full time and women dedicate themselves to housework. In the more traditional, strong family ties societies is the woman who is supposed to fulfill the family obligations and as such participate less in the market. According to EspingAndersen (1999), this gender relationship has been helped by a welfare state model that has historically delegated family care services for children and the elderly to the family sphere and has protected the male-breadwinner figure. Alesina and Ichino (2009) provide an in depth analysis of this type of family organization with respect to Italy.

\subsection{The impact of family ties}


In Tables 4-7, we present our results on the overall effects of family ties. Each attitude is regressed on our measure of family ties, some control variables (age, education, marital status and a gender dummy ${ }^{8}$ ), country specific effects and wave dummies. The sample size differs across regressions and range from a minimum of 26,974 to a maximum of $212,931^{9}$; therefore always providing substantial variation in time period and number of countries.

Before we comment on the results on the impact of family ties, it is useful to discuss the effect of our control variables. The results, which are of independent interest, are very reasonable and provide credibility to the measure of family ties we are going to use. There is a hump-shaped relationship in age between interest in politics, political participation and political action, and between age and job security. There is also a hump-shaped relationship between age and trust, whereas the level of trust in the family does not change with age. Emphasizing obedience is less important among young people and it has a U-shaped relationship with age. The same U-shaped relationship also exists for the attitudes looking at whether society should be defended versus whether it should be dramatically changed. Not surprising, young people believe that new ideas are better than old ones and are more open to major changes in life. Attitudes toward women are not systematically related to age. Gender and education also have the expected effects. Women are generally less interested and involved in politics than men. They also trust less (gender like age, however is not systematically related to the level of trust in the family, a more universal value that does not change with specific demographics). Not surprisingly women have less traditional beliefs about the role of women in society compared to their male counterparts (an indication that they most likely suffer from the presence of traditional gender role attitudes). Education is

\footnotetext{
8 We do not include income in our regressions since in the next section we do find that family ties could explain part of the differences in GDP per capita across countries. Our results are however robust to its inclusion.

${ }^{9}$ The smallest sample is for labor force participation of the elderly $(26,974)$, therefore the smaller sample size depends by the fact the regressions are not run on the whole population. The variable trust in the family is the one with substantially lower sample size, of around 10,000 observations.
} 
positively related to political interest and political action. More educated people have a higher level of trust, less traditional attitudes about the role of women in society; they also believe obedience is not an important quality to teach children. Finally they are in support of new ideas but more conservative with respect to major changes in life and in society ${ }^{10}$.

Let's now consider the effect of family ties. Table 4 , which relates to political participation and political action, shows that family ties have a negative and highly statistically significant coefficient. Regarding the magnitude of the effect, the beta coefficient of family ties on political participation (the first four columns of Table 4) is equal for the four different measures to 0.01 (roughly to $1 / 5$ of the magnitude of the beta coefficient of the middle level of education, which ranges between 0.04 and 0.05$)^{11}$. The magnitude of the beta coefficient for family ties is larger for the measures of political actions. In this case the coefficient goes from 0.04 to 0.08 and it is between $1 / 3$ or even the same effect of the middle level of education.

Table 5, which includes the same dummies and controls of Table 4, refers to those variables of "generalized morality" (as in Tabellini (2008)) and openness to new ideas. The results are as expected. Particularly important is the result of column 1 which shows a negative effect of family ties on generalized trust, but positive on trusting family members (column 2). Strong family ties imply teaching more obedience to children (column 3) and being relatively conservative in terms of personal and social change (columns 4, 5 and 6). As for the magnitude of the effects: the beta coefficients of family ties on trust is equal to -0.016 (half the coefficient of middle level of education, which has a positive effect compared to

\footnotetext{
${ }^{10}$ When we control for income as one of our robustness checks, we do find that income is positively correlated with trust and trust in the family, like education. Similarly income is inversely correlated with the importance of obedience. Income is however inversely correlated with the importance of new ideas and major changes in life, but positively correlated with the belief that society should be changed.

${ }^{11}$ We include two dummies for education: one for middle and one for upper level (the excluded group is lower level of education). The sign of the middle and upper level of education coefficient is positive, as the excluded group is lower level of education.
} 
the lower level of education). The impact of family ties on trusting the family is three times the effect of middle level of education; the magnitudes of middle level of education and family ties are equivalent (but of opposite sign) for obedience and the three attitudes on personal and social change (columns 4 to 6 ).

Table 6 looks at labor market of women, young adult and elderly. Individuals coming from strong family ties have a lower level of labor force participation for women, young adults and older people. This is consistent with the male-bread winner hypothesis according to which, women are the one supposed to stay at home and take care of the family, together with older and younger people. Consistent with the relationship postulated by Alesina et al. (2013), individuals with familistic values consider job security the most important characteristic in a job. The impact of family ties on the labor force participation of the three groups is small compared to the impact of education (the beta coefficient is $1 / 10$ when compared to the one on middle level of education). This is not surprising: family ties are very relevant in the determination of labor market institutions (see Alesina et al. (2013)) and the country fixed effects are most likely capturing part of that channel. The impact of family ties on job security (columns 4 and 5) on the other hand is six times larger than the effect of middle level of education.

Table 7 refers to the attitudes towards women. With the exception of column (2), in all other columns the variable family ties has the expected sign and it implies a more traditional role of women in the family. Indeed, this makes sense, with close family ties the family needs someone who organizes it, and keeps it together, typically the wife and mother. In this sense, the family becomes a formidable producer of goods and services which are not counted in standard measure of GDP, like childcare, care of the elderly and various other forms of home production. ${ }^{12}$ As for the magnitude of the effects it goes from roughly $1 / 4$ of

\footnotetext{
${ }^{12}$ See Alesina and Ichino (2009) for an empirical estimate of the size of home production in a few countries with weak or strong family ties.
} 
the effect of middle level of education (for the first four columns) to being more or less of equivalent magnitude (for the last three columns).

Overall we find that different beliefs about the importance of the family in one person's life and the relationship among generations are relevant for the determination of values, which have been proven to promote employment, innovation and growth. If values about the family are transmitted from generation to generation and they move slowly over time, they could provide an explanation on how the distant past can affect the current functioning of institutions. Indeed, several papers have provided evidence that attitudes toward the family and different forms of family structures are transmitted from generation to generation and affect the behavior of second generation immigrants, who still maintain the values and behavior of their parents despite living in an institutional environment which is very different than their ancestor's country of origin ${ }^{13}$. It is also worth notice that all the results presented in this section are most likely a lower bound of the effect of family ties. If family values become part of the national culture, this is captured by the country fixed effects together with the impact of institutions and all other time invariant characteristics.

\section{An aggregate perspective}

In this section we provide some suggestive evidence to support the idea that family ties are correlated with fundamental determinants of economic outcomes at the aggregate level. We document a strong correlation between the strength of family ties, economic development and quality of institutions. Countries where the family is an important institution have lower levels of per capita GDP and lower quality of institutions.

\footnotetext{
13 See Alesina and Giuliano (2010 and 2011) and Alesina et al. (2013). All these papers show that family ties have an effect of the behavior of second generation immigrants in the US and a large set of European countries. This evidence hints at the possibility that the partial correlations established in section 4 can have causal nature.
} 
We do our analysis in two steps. As a first step, we establish a basic correlation between the strength of family ties, economic development and the quality of institutions. As a second step, we show that family values brought by immigrants who arrived in several destination countries before 1940 are correlated with the level of development and the quality of institutions today.

We measure economic development with real GDP per capita. As a measure of institutional quality we use the Worldwide Governance Indicators (WGI) of the World Bank. The WGI reports on six broad dimensions of governance for over 200 countries for the period 1996-2011. These dimensions are: voice and accountability (the extent to which a country's citizens are able to participate in selecting their government, as well as freedom of expression, freedom of association and a free media), political stability and absence of violence (measuring perceptions of the likelihood that the government will be destabilized or overthrown by unconstitutional or violent means, including politically-motivated violence and terrorism), government effectiveness (about the quality of public services, the quality of the civil service and the degree of its independence from political pressures, the quality of policy formulation and implementation, and the credibility of the government's commitment to such policies), regulatory quality (the ability of the government to formulate and implement sound policies and regulations that permit and promote private sector development), rule of law (capturing perceptions of the extent to which agents have confidence in and abide by the rules of society, and in particular the quality of contract enforcement, property rights, the police, and the courts, as well as the likelihood of crime and violence) and control of corruption (the extent to which public power is exercised for private gain, including both petty and grand forms of corruption, as well as "capture" of the state by elites and private interests). 


\subsection{The correlation between family ties, economic development and institutional quality}

We first establish that countries with stronger family values have lower economic development on average, measured by GDP per capita (Table 8). We run cross-country regressions of GDP per capita on our measures of family values ${ }^{14}$. We show that the coefficient from a regression of logarithm of GDP per capita on the strength of family ties is highly negatively and significant. A one standard deviation increase in the strength of family ties (0.36) is associated with a reduction of the log of GDP per capita of 0.71 (roughly equal to 44 percent of its standard deviation). The second column controls for human capital, measured by the logarithm of the average schooling years in the total population over age 15. By adding this variable, we might be over controlling since educational choices might themselves be an outcome of family values. The strength of family ties is still very strong although is magnitude is, not surprisingly, reduced.

The cross-sectional correlations live open the possibility that other omitted variables can explain both the strength of family ties and differences in economic development across countries. Using the combined waves of the WVS we can limit this possibility by looking at the correlation between regional income and regional family ties, after controlling for country fixed effects. The results are reported in Table 9. To have a very large sample (more than 1000 regions) we constructed the income measure by collapsing the income variable from the WVS, instead of using estimates of regional GDP which are available only for a limited European sample $^{15}$. In column 1 , we report the correlation between regional income and the strength of family ties. Similarly to the cross country regressions the correlation is negative and significant at the one percent level. This correlation also exists once

\footnotetext{
${ }^{14}$ The measure of GDP is averaged between 1980 and 2010, the years in which the World Value Survey was taken. In particular, before taking the average we match each country with the GDP corresponding to the year in which the survey was taken.

${ }^{15}$ The income variable in the dataset indicates income scales and it coded as a variable going from one to eleven, where one indicate the lower step in the scale of incomes and eleven the highest.
} 
we control for country fixed effects with a smaller but still relevant magnitude: a one standard deviation increase in the strength of family ties (0.44) is associated with a reduction in income of 0.152 (roughly equal to 14 percent of its standard deviation). It is also interesting to note that the correlation exists in all different continents. Columns 3 to 7 indeed show that the correlation is quite strong not only inside Europe but also inside Africa and Asia ${ }^{16}$.

The next question is whether the negative relationship between GDP and family values is also reflected in a negative relationship between family values and institutions. We explore this question in Table 10. We find that the strength of family ties is associated with lower quality of institutions. The effect is always negative and significant for all different types of institutions. The effect is also sizeable: a one standard deviation increase in the strength of family ties (0.35) is for example associated with a reduction of the control of corruption measure of 0.61 (roughly equivalent to 54 percent of its standard deviation)

A recent literature has suggested that one important driver of many formal institutions is legal origin. For example English (common) law countries have been shown to have higher levels of investor protection, superior protection of property rights and a more efficient judicial system. When we control for legal origin (Table 11), the negative association between family ties and the quality of institutions stay virtually the same.

\subsection{Inherited family values and current institutions and development}

Our implicit assumption in all the empirical analysis is that family values change slowly, they are transmitted from generation to generation and they have persisted through history to the present day. This form of persistence seems intuitively likely given the probability that children are brought up to consider the attachment to the family, the respect for parents and the belief that they will do

${ }^{16}$ The results on North America and Oceania are not significant, most likely due to the small sample size. Similarly for South America. 
everything for their children as the natural state of the world. As a result, children will most likely reproduce the same values and beliefs with their own children. The persistence may develop and it can be facilitated through intermediate factors, such as the nature of political or economic institutions, shaped first by family structures which, in turn, have continued to influence our society today in a path-dependent manner.

In this section, we isolate the impact of cultural values on today's institutions. Ideally we would like to have measures of family values observed much before the measure of current institutions. Family values going so far back in time cannot be observed directly, since there is no survey available for that period of time. However, following Algan and Cahuc (2010) we can detect family ties by looking at family values inherited by children of immigrants in several European countries whose forbears arrived in Europe before 1940.

The idea behind this exercise is as follows: parental values are a good predictor of the values of children. For that reason we can use the family values that European descendants have inherited from their forebears who migrated to Europe from different countries before 1940 to know the values for the period preceding the quality of institutions today. This method allows us to cope with the lack of information on historical family values, by using the values that the descendants of various immigrants groups have inherited from their ancestors' countries of origin. This strategy is very useful because by using the values that European immigrants have inherited from the home country instead of the average values of the residents, we can exclude reverse causality.

To perform our exercise we use data from the European Social Survey (ESS). The ESS is a biennial cross-sectional survey administered in a large sample of mostly European nations. The survey was conducted five times: in 2002/2003, 2004/2005, 2006/2007, 2008/2009 and 2010/2011. The number of countries 
surveyed varies by wave. There are 22 countries included in the first round, 26 in the second, 25 in the third, 29 in the fourth, and 20 in the fifth. The sample size for a survey differs by country depending on its size. They range from 579 for Iceland to 2,870 for Germany.

Our primary sample consists of children of immigrants. We define children of immigrants as individuals born in a certain country but whose fathers were born $\operatorname{abroad}^{17}$. In order to get enough observations, we use information on second generation immigrants born before 1940. In the presence of cultural transmission children of immigrants should have inherited attitudes toward the families from their parents (who should have arrived in the destination countries not later than 1940 but possibly much earlier), who came to the destination countries with cultural attitudes from their countries of origin.

The European Social Survey does not contain the same variables on family ties as those of the World Values Survey. To measure the strength of family ties we use a question asking the respondent his/her level of agreement with the following statement: "A person's family should be the main priority in life" the answer can go from "disagree strongly" to "agree strongly" on a scale from one to five.

There is a strong correlation between the inherited family ties of the children of immigrants born before 1940 (as measured by the ESS question) and current family ties in the countries of origin of their parents (as proxied by our measure of family ties calculated from the WVS). The correlation is rather steady and equal to 0.35 , showing that there is a strong inertia in family values across countries.

We next discuss the correlation between the inherited family ties dating back to at least 60 years ago and current regulations in the home countries. Tables 12 and 13 show the OLS estimations, with and without the inclusion of legal origin

\footnotetext{
${ }^{17}$ We use the country of origin of the father to determine the origin of children of immigrants. When this information is not available we use the country of origin of the mother, if she is an immigrant. Natives are excluded from the analysis.
} 
dummies. We do find a robust and significant negative relationship between inherited family values and current institutions. The relationship holds even after controlling for legal origin. We do the same exercise with the level of development finding again a stable negative relationship between current development and inherited family values (columns 3 and 4 of Table 8). Overall we do find that there is a long lasting effect of family ties on the quality of current institutions.

\section{Family Ties: Implications for Well Being}

Strong family ties countries are characterized by less favorable economic outcomes and attitudes. Unemployment rate, labor force participation and income per capita are worse in strong family ties countries. Such unfavorable outcomes however do not seem to lead to dramatic situations of economic need in the population or to social unrest. This observation seems to suggest that in some sense those negative economic outcomes are less painful in strong family ties societies. In this part we review existing evidence on the positive effects of familistic societies and provide some additional one on the conjecture that family ties could indeed improve well-being.

Bentolila and Ichino (2008) study the relationship between unemployment and consumption in four different countries: Spain, Italy, Great Britain and the US. Their empirical results indicate that an increase in the duration of unemployment spells of male household heads is associated with smaller consumption losses in Spanish and Italian households. They conclude that extended family networks constitute the social institution which plays the crucial role of reducing the cost of unemployment near the Mediterranean. In Spain and Italy, the family appears to supplement for the lack of generosity of the welfare system and for the imperfection of capital markets. In this sense, the Mediterranean family based 
solution seems to produce a desirable outcome from a welfare point of view since it allows for more consumption smoothing.

Along similar lines, Alesina and Giuliano (2010) look at the amount of home production in strong family ties societies. Societies with strong family ties are associated with more time spent at home by wives/mothers and young adults living at home longer. This implies more home production (in the form of child care, home cooking, caring for the elderly, house cleaning, etc.). In addition, according to a more traditional role attributed to women in societies in strong family ties societies, these activities should be mostly performed by wives and daughters. The authors indeed find that the strength of family ties is relevant for the determination of home production of women, but not of men as expected.

Both examples live open the question of a general effect on well-being of the strength of family ties. This is a particularly important question because income per capita cannot properly measure economic development or well-being. On the one hand, as noticed above, home production is not included in the standard measures of GDP. More generally, there is a growing consensus that economic development is poorly measured by income per capita alone, and should include measures of life satisfaction. One reason for the inclusion of measures of life satisfaction is that the increase in income per capita within countries has not been associated with an increase in happiness (what is known as Easterlin paradox). To explain this result recent contributions suggest that well-being depend essentially on the quality of social relationships and not only on individual income. From this perspective, if social relationships are particularly good among family members, we should expect a strong correlation between family ties and well-being.

Table 14 illustrates this relationship using measures of subjective happiness and self-reported health.The first question asks the respondent, on scale from 1 to 4 , whether "Taking all things together, would you say you are", very happy (taking 
the value of 4), quite happy, not very happy, not at all happy (taking the value of 1). The second question asks "All things considered, how satisfied are you with your life as a whole these days?", the answer goes from dissatisfied (taking the value of 1) to satisfied (taking the value of 10). The last question asks the respondent, on a scale from 1 to 5, "All in all, how would you describe your state of health these days? Would you say it is Very good (taking the value of 5), good, fair, poor or very poor (taking the value of 1). All in all, although strong family ties can harm societies in a variety of ways, they can also have positive effects in an individual's life, as measured by happiness and self-reported measures of health.

\section{Conclusion}

We show that differences in family values have an impact on attitudes and outcomes that are relevant to explain differences in growth across countries and the quality of institutions. We study attitudes toward working women, the society, generalized morality and civic engagement. Our findings confirm an idea first developed by political scientists and sociologists: trust in the family prevent the formation of generalized trust, which is at the core of many collective good outcomes, from political participation to the formation of institutions to economic development. This should not be taken of course as a "criticism" of the family as a fundamental institution of society but as an analysis of the effect of different family arrangements. Our analysis indeed shows that family ties are related to different measures of happiness, life satisfaction and self-reported health. 


\section{References}

Acemoglu. D., S. Johnson and J. Robinson (2001), "The Colonial Origins of Comparative Development: An Empirical Investigation", American Economic Review, 91, 1369-1401.

Acemoglu, D., Johnson, S. and J. A. Robinson (2005), Institutions as the Fundamental Cause of Long-Run Economic Growth", in Handbook of Economic Growth, Philippe Aghion and Stephen Durlauf editors, Amsterdam: Elsevier B. V., 385-472.

Akerlof, G. and R. Kranton (2000), "Economics and Identity", Quarterly Journal of Economics, 115, 715-53.

Alesina, A., Y. Algan, P. Cahuc and P. Giuliano (2013), "Family Values and the Regulation of Labor", mimeo.

Alesina, A. and P. Giuliano (2010), "The Power of the Family", Journal of Economic Growth, 15: 93-125.

Alesina, A. and P. Giuliano (2011), "Family Ties and Political Participation", Journal of the European Economic Association, 9(5): 817-839.

Alesina, A., P. Giuliano and N. Nunn (2013), "On the Origins of Gender Roles: Women and the Plough", forthcoming, The Quarterly Journal of Economics.

Alesina, A. and A. Ichino (2009), L'Italia fatta in casa, Mondadori, Milano.

Algan, Y. and P. Cahuc (2007), "The Roots of Low European Employment: Family Culture?", NBER Macroeconomic Annual, Cambridge, MA: MIT Press.

Algan, Y. and P. Cahuc (2010), "Inherited Trust and Growth", American Economic Review, 100:2060-2092.

Almond, G. and S. Verba (1963), The Civic Culture: Political Attitudes and Democracy in Five Nations, Princeton University Press. 
Arrow, K. (1972), "Gifts and Exchanges", Philosophy and Public Affairs, 1(4), 343-362.

Banfield, E. (1958), The Moral Basis of a Backward Society, New York: Free Press.

Bentolila, S. and A. Ichino (2008), "Unemployment and Consumption Near and Far Away from the Mediterranean", Journal of Population Economics, 21, 255-280.

Bertrand, M. and A. Schoar (2006), "The Role of Family in Family Firms", Journal of Economic Perspectives, 20 (2): 73-96.

Boyd, R. and P. J. Richerson (1985), Culture and the Evolutionary Process, London: University of Chicago Press.

Castles, F. (1995), "Welfare State Development in Southern Europe", Western European Politics, 18, 201-213.

Coleman, J.S. (1988), "Social Capital in the Creation of Human Capital", American Journal of Sociology, XCIV, S95-S120.

Coleman, J. S. (1990), Foundations of Social Theory, Cambridge, MA: Harvard University Press.

Durante, R. (2010), "Risk, Cooperation and the Economic Origins of Social Trust: An Empirical Investigation”, Science Po, mimeo

Duranton, G. and A. Rodriguez-Pose (2009), "Family Types and the Persistence of Regional Disparities in Europe", Economic Geography, 85: 23-47.

Esping-Andersen, G. (1999), Social Foundation of Post-Industrial Economies, Oxford: Oxford University Press.

Fernandez, R. and A. Fogli (2009), "Culture: An empirical Investigation of Beliefs, Work and Fertility", American Economic Journal: Macroeconomics, 1(1), 146-177. 
Ferrera, M. (1996), "The Southern Model of Welfare in Social Europe”, Journal of the European Social Policy, 1, 17-37.

Fortin, N. (2005), "Gender Role Attitudes and the Labour Market Outcomes of Women Across OECD Countries", Oxford Review of Economic Policy, 21, 416-438.

Fukuyama, F. (1995), Trust: The Social Virtues and the Creation of Prosperity. New York: Free Press.

Galasso, V. and P. Profeta (2012), "When the State Mirrors the Family: The Design of Pension Systems", Bocconi University, mimeo.

Gambetta, D. (1988), ed. Trust: Making and Breaking Cooperative Relations, Blackwell.

Giavazzi, F., F. Schiantarelli and M. Serafinelli (2013), "Attitudes, Policies and Work", Journal of the European Economic Association, forthcoming

Gigerenzer, G. (2007), Gut Feelings: The Intelligence of the Unconscious, New York: Penguin Group.

Giuliano, P. (2007), "Living Arrangements in Western Europe: Does Cultural Origin Matter?", Journal of the European Economic Association, 5 (5), 927952.

Glaeser, E., La Porta, R., F. Lopez de Silanes and A. Shleifer (2004), "Do Institutions Cause Growth", Journal of Economic Growth, 9, 271-304.

Glaeser, E., Ponzetto, G. and A. Shleifer (2007), "Why Democracy Need Education?", Journal of Economic Growth, 12 (2), 77-99.

Gorodnichenko, Y. and G. Roland (2011), "Culture, Institutions and the Wealth of Nations", UC Berkeley, mimeo.

Greif, A. (1994), "Cultural Beliefs and the Organization of Society: A Historical and Theoretical Reflection on Collectivist and Individualist Societies", Journal of Political Economy, 5 (102). 
Greif A. (2005), "Family Structure, Institutions and Growth: The Origin and Implications of Western Corporatism", American Economic Review, Papers and Proceedings.

Greif, A. (2006), Institutions and the Path to the Modern Economy: Lessons from Medieval Trade”, Cambridge: Cambridge University Press.

Greif, A. and G. Tabellini (2012), "The Clan and the City: Sustaining Cooperation in China and Europe", Stanford, mimeo.

Guiso, L., P. Sapienza and L. Zingales (2006), "Does Culture Affect Economic Outcomes?", Journal of Economic Perspectives, Spring.

Guiso, L., P. Sapienza and L. Zingales (2008), "Long Term Persistence”, NBER WP 14278.

Guiso, L., P. Sapienza and L. Zingales (2010), "Social Capital as Good Culture", Journal of the European Economic Association, 6(2-3), 295-320.

Kanhneman, D.( 2011), Thinking, Fast and Slow, New York: Farar, Straus and Giroux.

Korpi, W. (2000), "Faces of Inequality: Gender, Class and Patterns of Inequalities in Different Types of Welfare States", Social Politics, 7, 127-191.

Lipset, S. M. (1959), "Some Social Requisites of Democracy: Economic Development and Political Legitimacy", American Political Science Review 53, 69-105.

Murdock, P. M. (1949), Social Structure, New York: Free Press.

North, D. (1981), Structure and Change in Economic History, Norton, New York.

North, D. C. (1990), Institutions, Institutional Change and Economic Performance, New York: Cambridge University Press.

Persson, T. and G. Tabellini (2009), "Democratic Capital: The Nexus of Political and Economic Change", American Economic Journal: Macroeconomics, 1(2), 88-126. 
Platteau, J. P. (2000), Institutions, Social Norms, and Economic Development, Academic Publishers and Routledge.

Putnam, R. (1993), Making Democracy Work: Civic Traditions in Modern Italy, Princeton University Press.

Putnam, R. (2000): Bowling Alone: The collapse and revival of American community, New York, NY: Simon and Schuster.

Spolaore, E. and R. Wacziarg (2009), “The Diffusion of Development”, Quarterly Journal of Economics, 124 (2), 469-529.

Tabellini, G. (2008), "The Scope of Cooperation: Values and Incentives", Quarterly Journal of Economics, 123 (3), 905-950.

Tabellini, G. (2010), "Culture and Institutions: Economic Development in the Regions of Europe", Journal of the European Economic Association, 8 (4), 677-716.

Todd, E. (1983), The Explanation of Ideology: Family Structures and Social Systems, New York: Basic Blackwell.

Todd, E. (1990), L'invention de l'Europe, Paris: Seuil.

Weber, Max (1904), The Protestant Ethic and the Spirit of Capitalism, New York: Scribner's Press. 
Figure 1

Strength of family ties, principal component

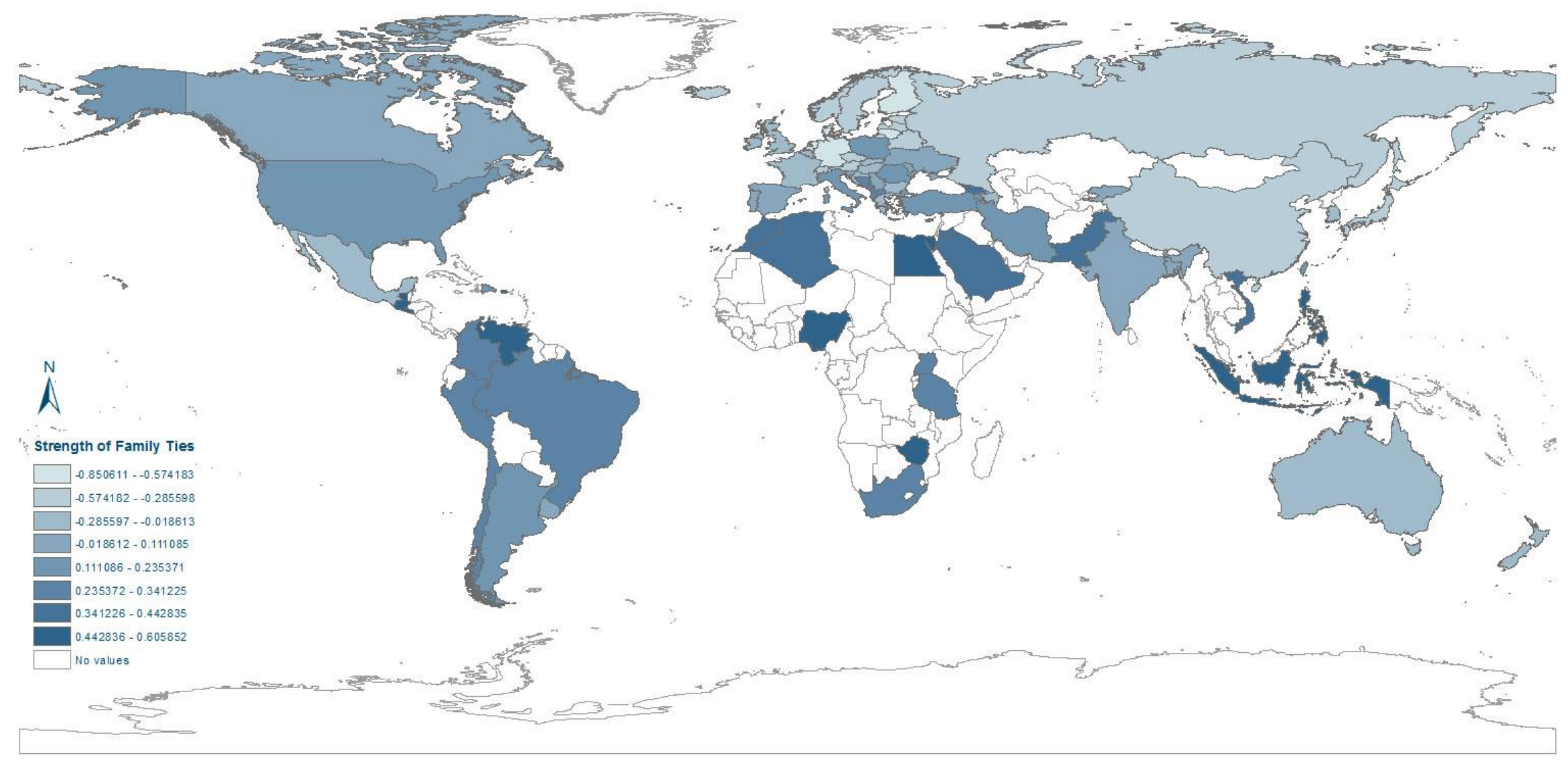

Source: Authors' calculation from the World Value Survey 
Figure 2

Family importance

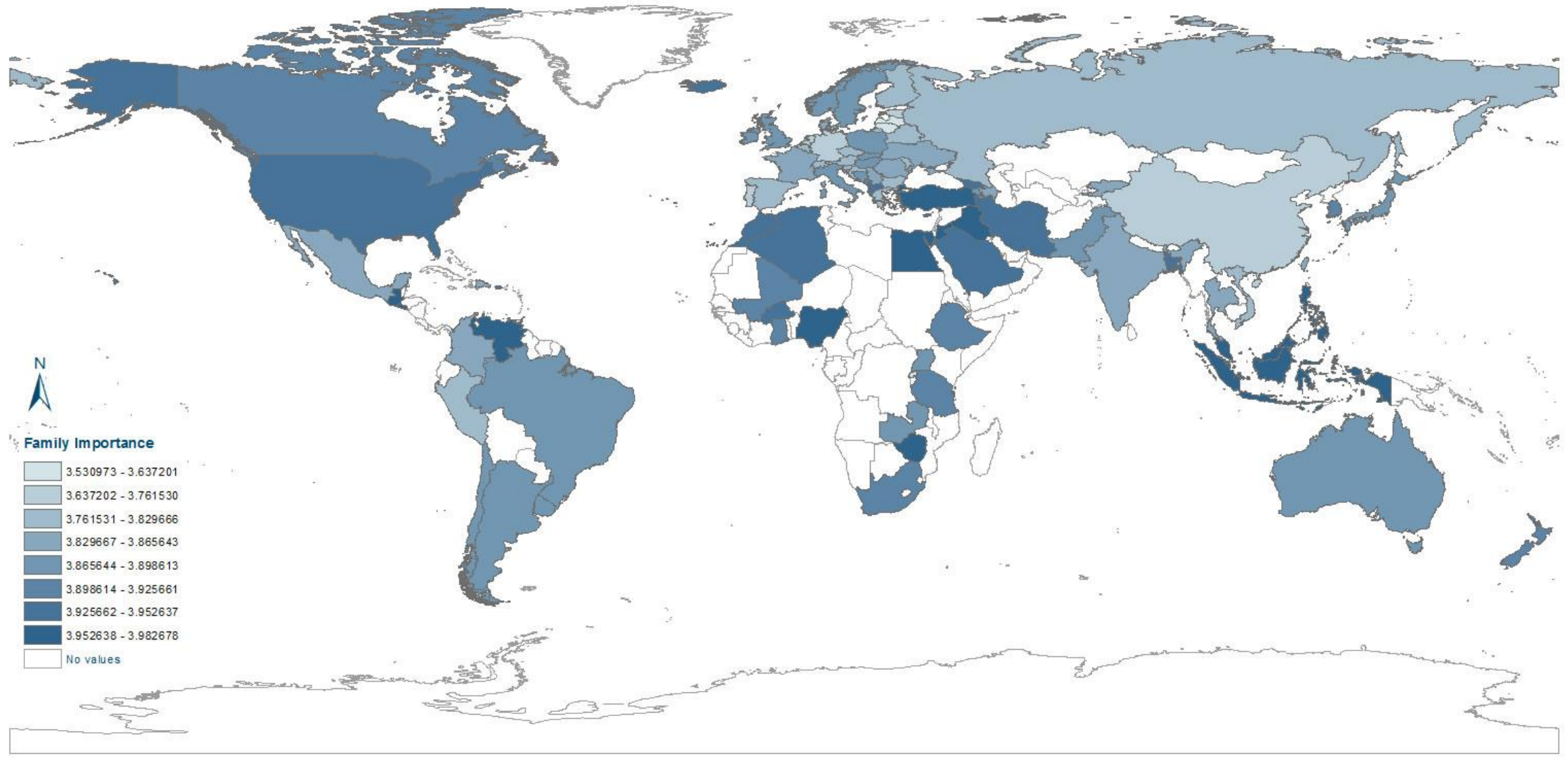

Source: Authors' calculation from the World Value Survey 
Figure 3

Respect and love for parents

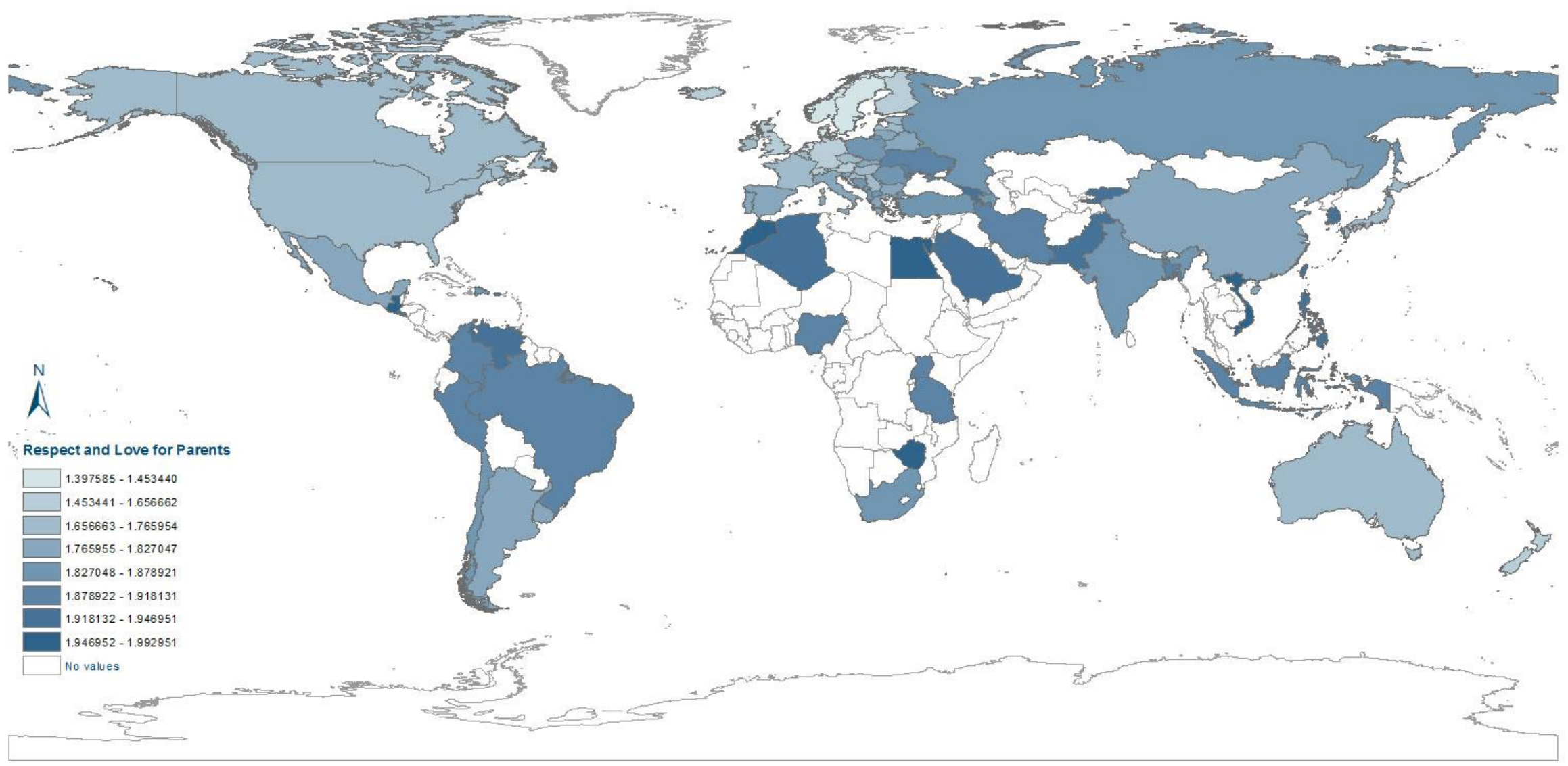

Source: Authors' calculation from the World Value Survey 
Figure 4

Parents' responsibilities to their children

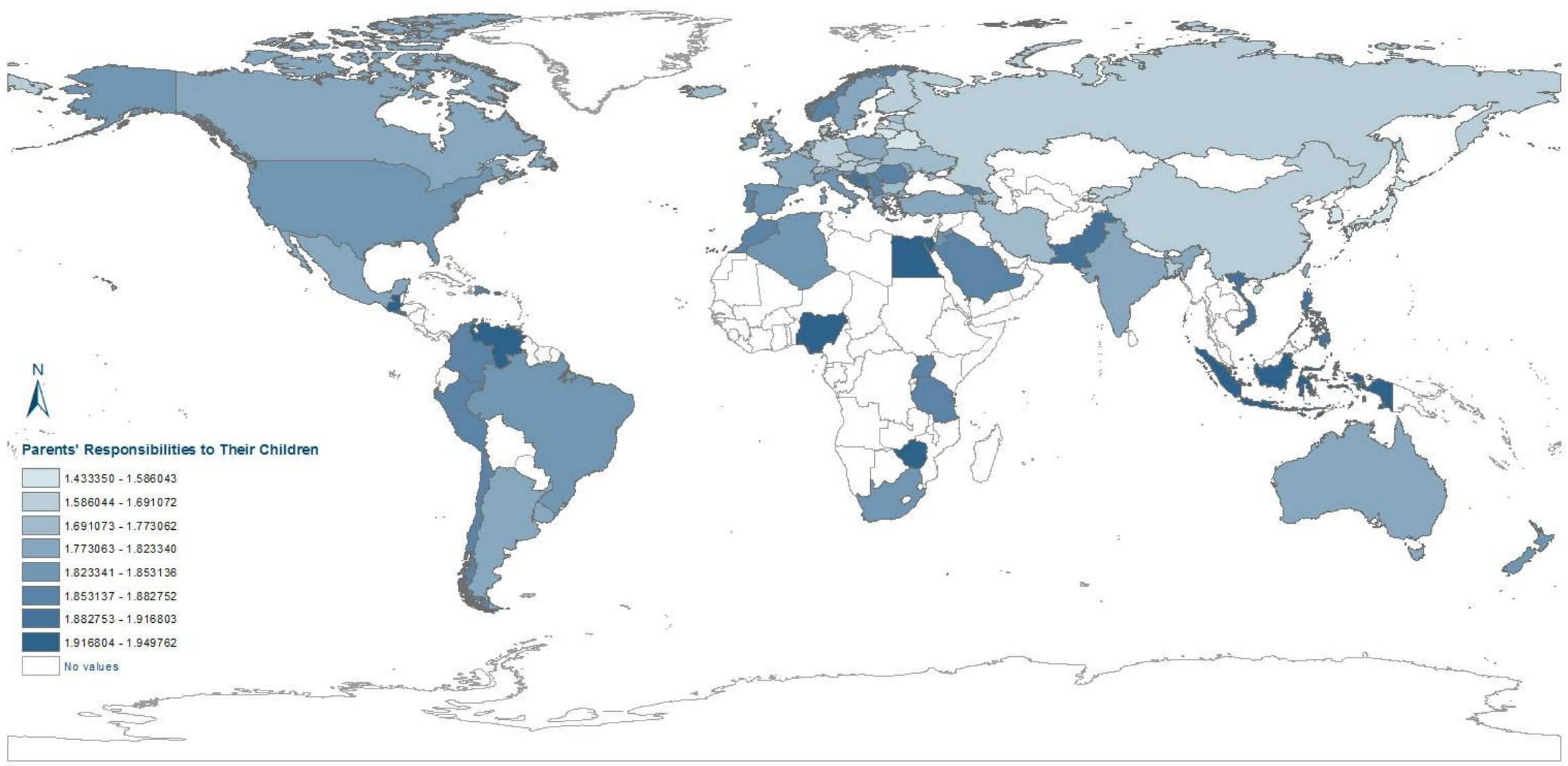


Figure 5

Strength of family ties

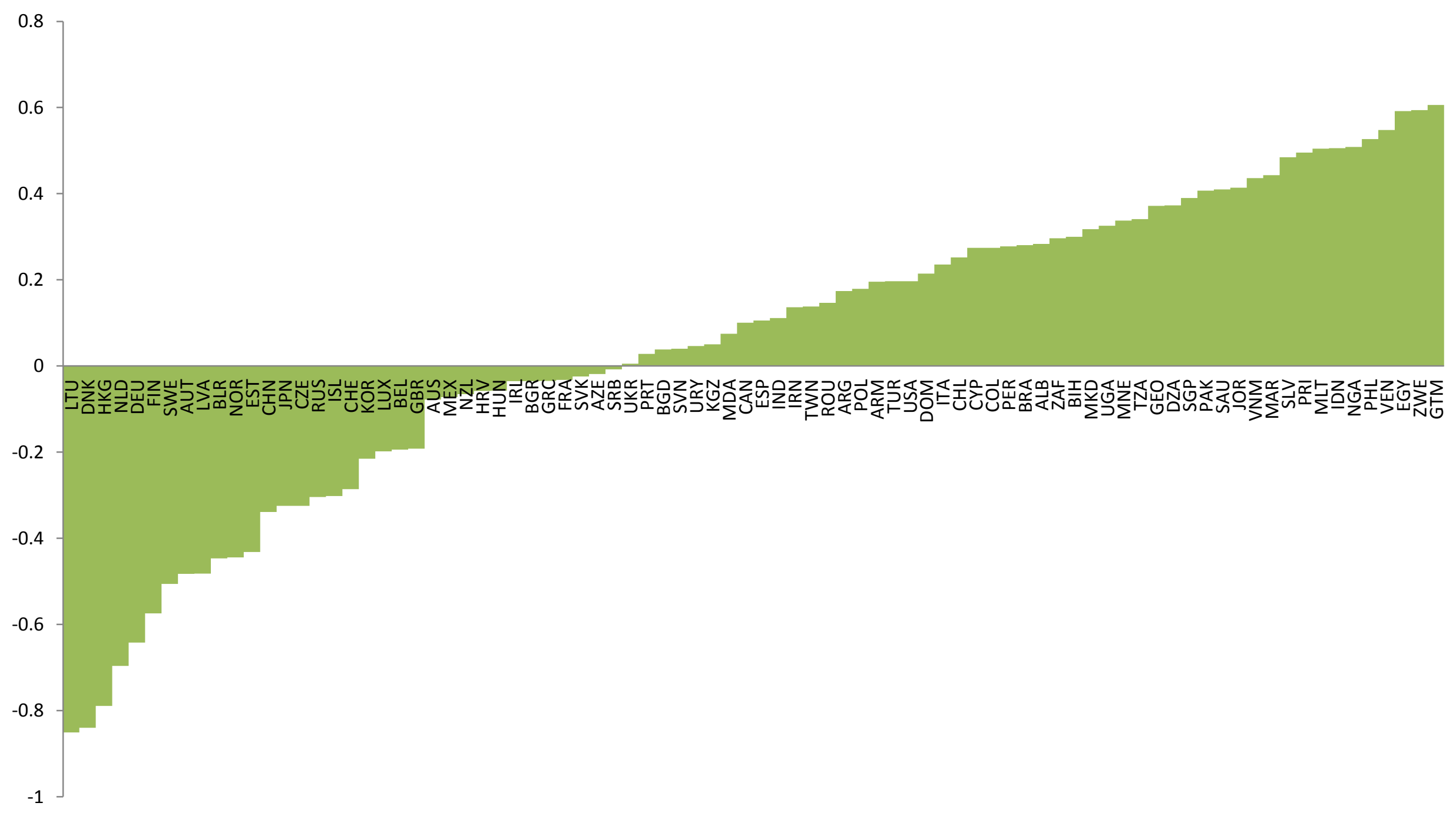


Figure 6

Generalized trust and the strength of family ties, regional variation inside Europe

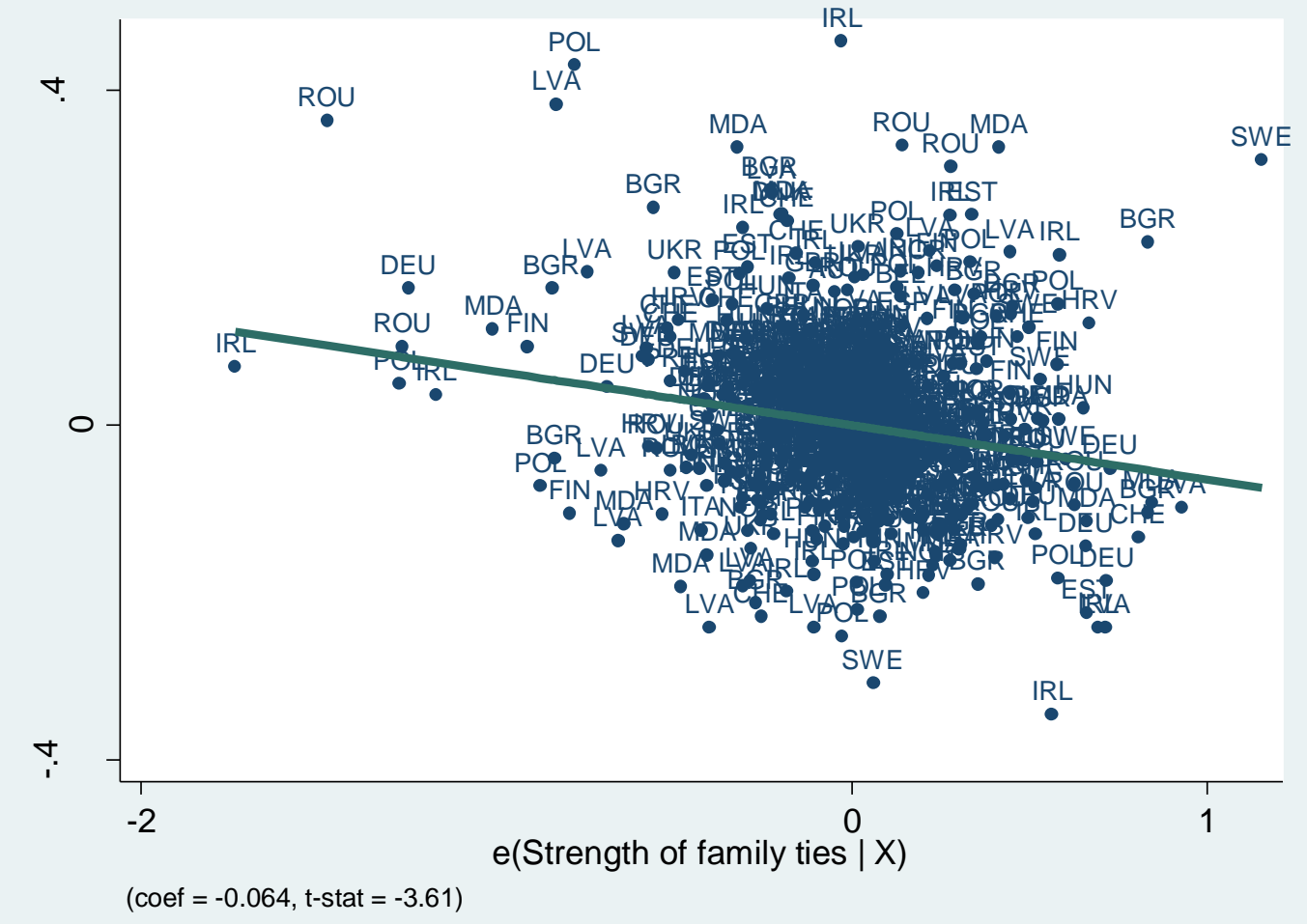


Figure 7

Family Structures, Todd's classification

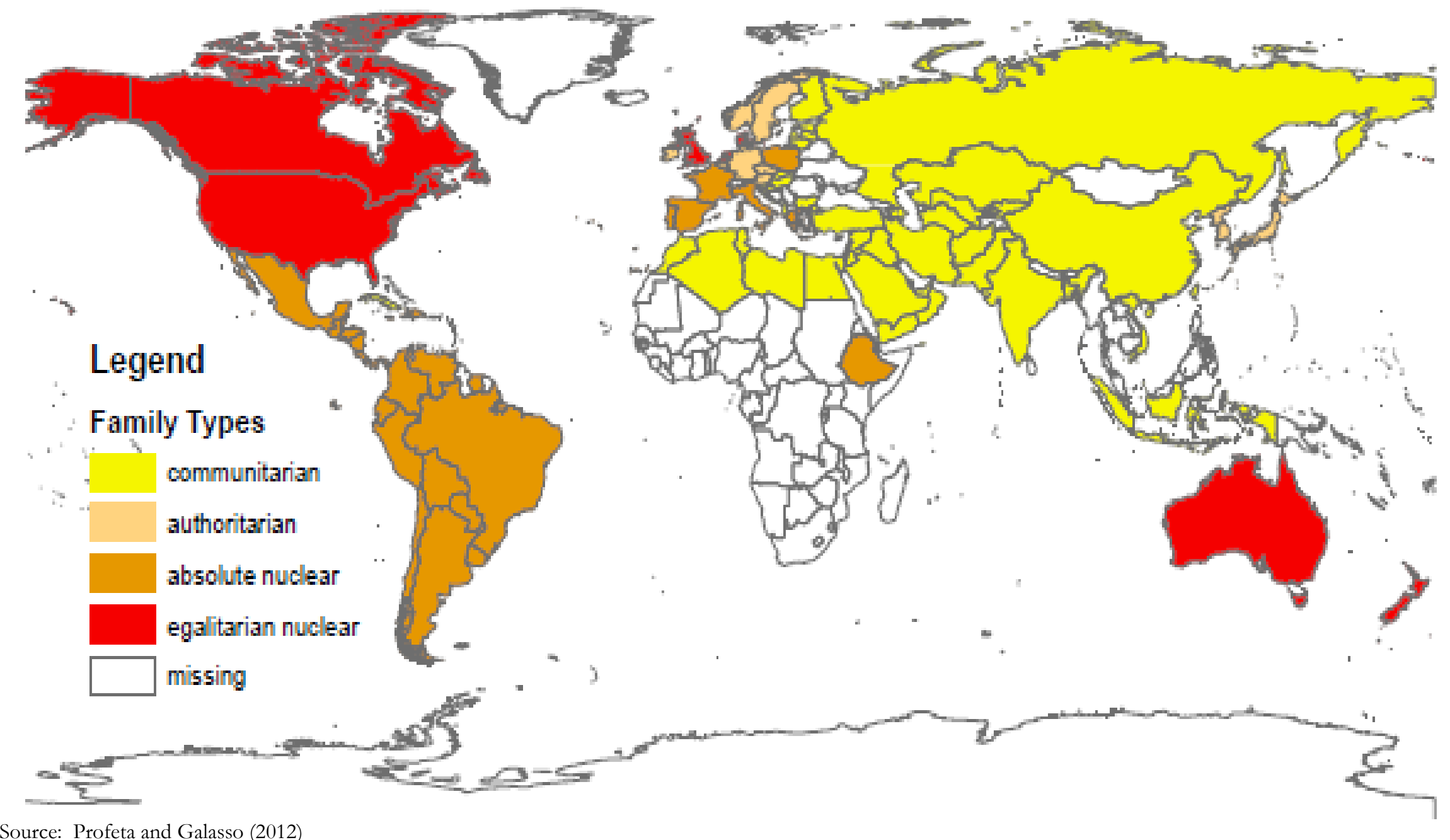

Source: Profeta and Galasso (2012) 
Table 1

Correlation among family values

\begin{tabular}{lcccc}
\hline \hline & Family importance & $\begin{array}{c}\text { Respect and love } \\
\text { parents }\end{array}$ & Parental duties & $\begin{array}{c}\text { Family ties } \\
\text { (princ. comp.) }\end{array}$ \\
Family importance & 1.0000 & 1.0000 & \\
Respect and love parents & $0.3446^{* *}$ & $0.3495^{* *}$ & 1.0000 & \\
Parental duties & $0.5518^{* * *}$ & $0.7944^{* * *}$ & $0.7928^{* * *}$ & 1.0000 \\
Family ties (princ. comp.) & $0.7217^{* * *}$ & & \\
\hline
\end{tabular}

Table 2

Relationship between the strength of family ties (WVS) and Todd's family structure

\begin{tabular}{lccc}
\hline \hline & $(1)$ & $(2)$ & $(3)$ \\
& Family important & Respect and love parents & Parental duties \\
\hline Communitarian family & 0.039 & $-0.135^{* *}$ & $0.086^{* * *}$ \\
& $(0.040)$ & $(0.065)$ & $(0.031)$ \\
Authoritarian family & 0.019 & 0.012 & $0.163^{* * *}$ \\
& $(0.033)$ & $(0.088)$ & $(0.049)$ \\
Nuclear egalitarian family & 0.018 & $-0.142^{* *}$ & 0.014 \\
& $(0.035)$ & $(0.065)$ & $(0.025)$ \\
Observations & 101,169 & 94,631 & 89,011 \\
R-squared & 0.007 & 0.037 & 0.028 \\
\hline \hline
\end{tabular}

Source: Galasso and Profeta (2012). A higher number in their specification indicates weaker family ties. Data are taken from the WVS. Each specification controls for a quadratic in age, education, income and political orientation. $* * *, * *$ and $*$ indicate significance at the 1,5 and $10 \%$ levels. 
Table 3

Family Ties and Climate Variability

\begin{tabular}{|c|c|c|c|c|}
\hline \multicolumn{5}{|c|}{ PANEL A: Climate data: $1500-1750$ and 1900-2000 } \\
\hline & \multicolumn{4}{|c|}{ Family Ties (principal component from WVS) } \\
\hline & \multicolumn{2}{|c|}{ Precipitation } & \multicolumn{2}{|c|}{ Temperature } \\
\hline & (1) & $(2)$ & (3) & (4) \\
\hline Variability (growing season months) & $-0.205^{* *}$ & $-0.300 * *$ & $-0.205^{* *}$ & $-0.306^{* * *}$ \\
\hline$(1500-1750)$ & $(0.085)$ & $(0.112)$ & $(0.081)$ & $(0.100)$ \\
\hline Variability (growing season months) & & $0.129 *$ & & 0.138 \\
\hline$(1900-2000)$ & & $(0.074)$ & & $(0.081)$ \\
\hline Observations & 218 & 218 & 218 & 218 \\
\hline Number of clusters & 24 & 24 & 24 & 24 \\
\hline R-squared & 0.830 & 0.833 & 0.785 & 0.789 \\
\hline \multicolumn{5}{|c|}{ PANEL B: Climate data: $1900-2000$} \\
\hline \multirow{3}{*}{ Climate data 1900-2000 } & \multicolumn{4}{|c|}{ Family Ties (principal component from WVS) } \\
\hline & \multicolumn{2}{|c|}{ Precipitation } & \multicolumn{2}{|c|}{ Temperature } \\
\hline & (1) & $(2)$ & (3) & (4) \\
\hline Variability & $-0.072^{* *}$ & & $-0.392 *$ & \\
\hline (12 months) & $(0.033)$ & & $(0.214)$ & \\
\hline Variability & & $-0.081 * * *$ & & $-0.692 * * *$ \\
\hline (growing season months) & & $(0.029)$ & & $(0.219)$ \\
\hline Variability & & -0.004 & & 0.063 \\
\hline (non-growing season months) & & $(0.024)$ & & $(0.130)$ \\
\hline Observations & 220 & 220 & 220 & 220 \\
\hline Number of clusters & 24 & 24 & 24 & 24 \\
\hline R-squared & 0.826 & 0.828 & 0.826 & 0.832 \\
\hline
\end{tabular}

Source: Durante (2010). The regressions control for country fixed effects and for the following regional controls: mean temperature, mean precipitation, average ruggedness index, soil suitability (average and standard deviation), area, dummy for landlocked, distance of the region's centroid from the coast, number of major rivers passing through the region, latitude of the region's centroid. Robust standard errors clustered at the country level in parenthesis. ${ }^{* * *}{ }^{* *}$ and $*$ indicated significance at the 1,5 and $10 \%$ level. 
Table 4

Family ties and political participation

\begin{tabular}{|c|c|c|c|c|c|c|c|c|c|}
\hline VARIABLES & $\begin{array}{l}\text { (1) } \\
\text { Interest in } \\
\text { politics }\end{array}$ & $\begin{array}{c}\text { (2) } \\
\text { Discuss } \\
\text { politics }\end{array}$ & $\begin{array}{c}(3) \\
\text { Belong to } \\
\text { political } \\
\text { parties }\end{array}$ & $\begin{array}{c}\text { (4) } \\
\text { Membership } \\
\text { political } \\
\text { party }\end{array}$ & $\begin{array}{c}\text { (5) } \\
\text { Sign } \\
\text { petition }\end{array}$ & $\begin{array}{c}\text { (6) } \\
\text { Join in } \\
\text { boycotts }\end{array}$ & $\begin{array}{c}(7) \\
\text { Attend } \\
\text { demonstrations }\end{array}$ & $\begin{array}{c}\text { (8) } \\
\text { Join } \\
\text { unofficial } \\
\text { strikes } \\
\end{array}$ & $\begin{array}{c}\text { (9) } \\
\text { Occupy } \\
\text { buildings }\end{array}$ \\
\hline Family ties & $\begin{array}{c}-0.010^{* * *} \\
(0.002)\end{array}$ & $\begin{array}{c}-0.006 * * * \\
(0.001)\end{array}$ & $\begin{array}{c}-0.002 * * * \\
(0.001)\end{array}$ & $\begin{array}{c}-0.004^{* *} \\
(0.002)\end{array}$ & $\begin{array}{c}-0.029 * * * \\
(0.002)\end{array}$ & $\begin{array}{c}-0.046^{* * *} \\
(0.002)\end{array}$ & $\begin{array}{c}-0.036 * * * \\
(0.002)\end{array}$ & $\begin{array}{c}-0.041 * * * \\
(0.002)\end{array}$ & $\begin{array}{c}-0.026^{* * *} \\
(0.001)\end{array}$ \\
\hline Age & $\begin{array}{c}0.016^{* * *} \\
(0.001)\end{array}$ & $\begin{array}{c}0.018^{* * *} \\
(0.000)\end{array}$ & $\begin{array}{c}0.002^{* * *} \\
(0.000)\end{array}$ & $\begin{array}{c}0.006^{* * *} \\
(0.001)\end{array}$ & $\begin{array}{c}0.012^{* * *} \\
(0.001)\end{array}$ & $\begin{array}{c}0.008^{* * *} \\
(0.001)\end{array}$ & $\begin{array}{c}0.009 * * * \\
(0.001)\end{array}$ & $\begin{array}{c}0.004^{* * *} \\
(0.000)\end{array}$ & $\begin{array}{l}-0.000 \\
(0.000)\end{array}$ \\
\hline Age squared & $\begin{array}{c}-0.000^{* * *} \\
(0.000)\end{array}$ & $\begin{array}{c}-0.000 * * * \\
(0.000)\end{array}$ & $\begin{array}{c}-0.000^{* * *} \\
(0.000)\end{array}$ & $\begin{array}{c}-0.000 * * * \\
(0.000)\end{array}$ & $\begin{array}{c}-0.000 * * * \\
(0.000)\end{array}$ & $\begin{array}{c}-0.000 * * * \\
(0.000)\end{array}$ & $\begin{array}{c}-0.000^{* * *} \\
(0.000)\end{array}$ & $\begin{array}{c}-0.000^{* * *} \\
(0.000)\end{array}$ & $\begin{array}{c}-0.000^{* * * *} \\
(0.000)\end{array}$ \\
\hline Female & $\begin{array}{c}-0.277 * * * \\
(0.004)\end{array}$ & $\begin{array}{c}-0.189 * * * \\
(0.003)\end{array}$ & $\begin{array}{c}-0.034 * * * \\
(0.001)\end{array}$ & $\begin{array}{c}-0.083^{* * *} \\
(0.004)\end{array}$ & $\begin{array}{c}-0.088^{* * *} \\
(0.004)\end{array}$ & $\begin{array}{c}-0.123^{* * *} \\
(0.003)\end{array}$ & $\begin{array}{c}-0.155^{* * *} \\
(0.004)\end{array}$ & $\begin{array}{c}-0.099 * * * \\
(0.003)\end{array}$ & $\begin{array}{c}-0.058^{* * *} \\
(0.002)\end{array}$ \\
\hline Married & $\begin{array}{l}-0.008 \\
(0.011)\end{array}$ & $\begin{array}{c}-0.016^{* *} \\
(0.007)\end{array}$ & $\begin{array}{c}0.010^{* *} \\
(0.004)\end{array}$ & $\begin{array}{c}0.009 \\
(0.008)\end{array}$ & $\begin{array}{c}0.002 \\
(0.009)\end{array}$ & $\begin{array}{c}0.023^{* * *} \\
(0.009)\end{array}$ & $\begin{array}{c}0.018^{* *} \\
(0.009)\end{array}$ & $\begin{array}{c}0.044^{* * *} \\
(0.008)\end{array}$ & $\begin{array}{c}0.029 * * * \\
(0.006)\end{array}$ \\
\hline Education dummies & yes & yes & yes & yes & yes & yes & yes & yes & yes \\
\hline Country dummies & yes & yes & yes & yes & yes & yes & yes & yes & yes \\
\hline Wave dummies & yes & yes & yes & yes & yes & yes & yes & yes & yes \\
\hline Observations & 212,931 & 220,148 & 133,684 & 66,407 & 131,066 & 127,491 & 131,408 & 126,513 & 125,180 \\
\hline $\mathrm{R}$-squared & 0.136 & 0.115 & 0.060 & 0.181 & 0.278 & 0.182 & 0.143 & 0.096 & 0.096 \\
\hline
\end{tabular}


Table 5

Family ties, generalized morality and attitudes toward society

\begin{tabular}{|c|c|c|c|c|c|c|}
\hline & $\begin{array}{c}\text { (1) } \\
\text { Trust }\end{array}$ & $\begin{array}{l}\text { (2) } \\
\text { Trust the } \\
\text { family }\end{array}$ & $\begin{array}{c}\text { (3) } \\
\text { Children } \\
\text { qualities: } \\
\text { obedience }\end{array}$ & $\begin{array}{l}\text { (4) } \\
\text { New and } \\
\text { old idea }\end{array}$ & $\begin{array}{l}(5) \\
\text { Major } \\
\text { change in } \\
\text { life }\end{array}$ & $\begin{array}{c}(6) \\
\text { Society } \\
\text { changed/society } \\
\text { defended }\end{array}$ \\
\hline Family ties & $\begin{array}{c}-0.006 * * * \\
(0.001)\end{array}$ & $\begin{array}{c}0.069 * * * \\
(0.008)\end{array}$ & $\begin{array}{c}0.024 * * * \\
(0.001)\end{array}$ & $\begin{array}{c}0.050^{* * *} \\
(0.009)\end{array}$ & $\begin{array}{c}0.112^{* * *} \\
(0.010)\end{array}$ & $\begin{array}{c}0.017 * * * \\
(0.002)\end{array}$ \\
\hline Age & $\begin{array}{c}0.002^{* * *} \\
(0.000)\end{array}$ & $\begin{array}{c}0.002 \\
(0.003)\end{array}$ & $\begin{array}{c}-0.004 * * * \\
(0.000)\end{array}$ & $\begin{array}{c}0.027 * * * \\
(0.003)\end{array}$ & $\begin{array}{c}0.015^{* * *} \\
(0.004)\end{array}$ & $\begin{array}{c}-0.002 * * * \\
(0.001)\end{array}$ \\
\hline Age squared & $\begin{array}{c}-0.000 * * * \\
(0.000)\end{array}$ & $\begin{array}{l}-0.000 \\
(0.000)\end{array}$ & $\begin{array}{c}0.000^{* * *} \\
(0.000)\end{array}$ & $\begin{array}{l}-0.000 \\
(0.000)\end{array}$ & $\begin{array}{c}0.000 \\
(0.000)\end{array}$ & $\begin{array}{c}0.000^{* * *} \\
(0.000)\end{array}$ \\
\hline Female & $\begin{array}{c}-0.006^{* * *} \\
(0.002)\end{array}$ & $\begin{array}{l}-0.002 \\
(0.014)\end{array}$ & $\begin{array}{l}-0.003 \\
(0.002)\end{array}$ & $\begin{array}{c}0.090^{* * *} \\
(0.019)\end{array}$ & $\begin{array}{c}0.086^{* * *} \\
(0.022)\end{array}$ & $\begin{array}{c}0.032^{* * *} \\
(0.003)\end{array}$ \\
\hline Married & $\begin{array}{c}-0.013 * * * \\
(0.005)\end{array}$ & $\begin{array}{c}-0.083^{*} \\
(0.043)\end{array}$ & $\begin{array}{c}0.002 \\
(0.005)\end{array}$ & $\begin{array}{l}-0.002 \\
(0.042)\end{array}$ & $\begin{array}{c}-0.182^{* * *} \\
(0.052)\end{array}$ & $\begin{array}{l}-0.003 \\
(0.008)\end{array}$ \\
\hline $\begin{array}{l}\text { Education dummies } \\
\text { Country dummies } \\
\text { Wave dummies }\end{array}$ & $\begin{array}{l}\text { yes } \\
\text { yes } \\
\text { yes }\end{array}$ & $\begin{array}{l}\text { yes } \\
\text { yes } \\
\text { yes }\end{array}$ & $\begin{array}{l}\text { yes } \\
\text { yes } \\
\text { yes }\end{array}$ & $\begin{array}{l}\text { yes } \\
\text { yes } \\
\text { yes }\end{array}$ & $\begin{array}{l}\text { yes } \\
\text { yes } \\
\text { yes }\end{array}$ & $\begin{array}{l}\text { yes } \\
\text { yes } \\
\text { yes }\end{array}$ \\
\hline $\begin{array}{l}\text { Observations } \\
\text { R-squared }\end{array}$ & $\begin{array}{c}217,647 \\
0.104\end{array}$ & $\begin{array}{l}9,802 \\
0.057\end{array}$ & $\begin{array}{c}220,639 \\
0.111\end{array}$ & $\begin{array}{c}81,640 \\
0.131\end{array}$ & $\begin{array}{c}69,736 \\
0.083\end{array}$ & $\begin{array}{c}110,077 \\
0.050\end{array}$ \\
\hline
\end{tabular}


Table 6

Family ties, labor market and attitudes toward work

\begin{tabular}{|c|c|c|c|c|c|}
\hline & $\begin{array}{c}\text { (1) } \\
\text { Female } \\
\text { LFP }\end{array}$ & $\begin{array}{l}\text { Youth } \\
\text { LFP }\end{array}$ & $\begin{array}{l}\text { Elderly } \\
\text { LFP }\end{array}$ & $\begin{array}{c}\text { (4) } \\
\text { Job } \\
\text { security }\end{array}$ & $\begin{array}{c}\text { (5) } \\
\text { Job } \\
\text { security } \\
\text { in looking } \\
\text { for job } \\
\end{array}$ \\
\hline Family ties & $\begin{array}{c}-0.013^{* * *} \\
(0.001)\end{array}$ & $\begin{array}{c}-0.012^{* * *} \\
(0.001)\end{array}$ & $\begin{array}{c}-0.006^{* *} \\
(0.003)\end{array}$ & $\begin{array}{c}0.017 * * * \\
(0.001)\end{array}$ & $\begin{array}{c}0.022^{* * *} \\
(0.001)\end{array}$ \\
\hline Age & $\begin{array}{c}0.063^{* * *} \\
(0.001)\end{array}$ & $\begin{array}{c}-0.043 * * * \\
(0.007)\end{array}$ & $\begin{array}{l}-0.050 \\
(0.043)\end{array}$ & $\begin{array}{c}0.003^{* * *} \\
(0.000)\end{array}$ & $\begin{array}{c}0.004 * * * \\
(0.000)\end{array}$ \\
\hline Age squared & $\begin{array}{c}-0.001 * * * \\
(0.000)\end{array}$ & $\begin{array}{c}0.001^{* * *} \\
(0.000)\end{array}$ & $\begin{array}{l}-0.000 \\
(0.000)\end{array}$ & $\begin{array}{c}-0.000 * * * \\
(0.000)\end{array}$ & $\begin{array}{c}-0.000 * * * \\
(0.000)\end{array}$ \\
\hline Married & $\begin{array}{l}-0.006 \\
(0.007)\end{array}$ & $\begin{array}{c}-0.060 * * * \\
(0.007)\end{array}$ & $\begin{array}{c}0.028 \\
(0.020)\end{array}$ & $\begin{array}{l}-0.000 \\
(0.005)\end{array}$ & $\begin{array}{l}-0.001 \\
(0.007)\end{array}$ \\
\hline Female & & $\begin{array}{c}-0.268^{* * *} \\
(0.003)\end{array}$ & $\begin{array}{c}-0.264 * * * \\
(0.005)\end{array}$ & $\begin{array}{c}-0.004^{* *} \\
(0.002)\end{array}$ & $\begin{array}{l}-0.003 \\
(0.003)\end{array}$ \\
\hline Education dummies & yes & yes & yes & yes & yes \\
\hline Country dummies & yes & yes & yes & yes & yes \\
\hline Wave dummies & yes & yes & yes & yes & yes \\
\hline Observations & 98,218 & 44,336 & 26,974 & 213,576 & 99,749 \\
\hline R-squared & 0.224 & 0.269 & 0.251 & 0.106 & 0.049 \\
\hline
\end{tabular}


Table 7

Family ties and attitudes towards women

\begin{tabular}{|c|c|c|c|c|c|c|c|}
\hline & Job scarce & $\begin{array}{l}\quad(2) \\
\text { Working } \\
\text { mother }\end{array}$ & $\begin{array}{l}\text { (3) } \\
\text { Housewife } \\
\text { fulfilling }\end{array}$ & $\begin{array}{c}(4) \\
\text { Men } \\
\text { political } \\
\text { leaders } \\
\end{array}$ & $\begin{array}{l}\quad(5) \\
\text { University } \\
\text { important } \\
\text { for girls }\end{array}$ & $\begin{array}{c}\text { (6) } \\
\text { Child } \\
\text { working } \\
\text { mother } \\
\end{array}$ & $\begin{array}{c}(7) \\
\text { Women } \\
\text { home } \\
\text { children } \\
\end{array}$ \\
\hline Family ties & $\begin{array}{c}0.015^{* * *} \\
(0.001)\end{array}$ & $\begin{array}{l}-0.002 \\
(0.002)\end{array}$ & $\begin{array}{c}0.044 * * * \\
(0.002)\end{array}$ & $\begin{array}{c}0.023^{* * *} \\
(0.003)\end{array}$ & $\begin{array}{c}0.008^{* * *} \\
(0.003)\end{array}$ & $\begin{array}{c}0.043^{* * *} \\
(0.004)\end{array}$ & $\begin{array}{c}0.075^{* * *} \\
(0.004)\end{array}$ \\
\hline Age & $\begin{array}{c}0.001 * * * \\
(0.000)\end{array}$ & $\begin{array}{l}-0.001 \\
(0.001)\end{array}$ & $\begin{array}{l}0.001 * \\
(0.001)\end{array}$ & $\begin{array}{c}0.002 \\
(0.001)\end{array}$ & $\begin{array}{c}0.001 \\
(0.001)\end{array}$ & $\begin{array}{c}0.006^{* * *} \\
(0.002)\end{array}$ & $\begin{array}{c}0.003 * * \\
(0.002)\end{array}$ \\
\hline Age squared & $\begin{array}{l}0.000 * * \\
(0.000)\end{array}$ & $\begin{array}{c}0.000^{* * *} \\
(0.000)\end{array}$ & $\begin{array}{c}0.000 * * \\
(0.000)\end{array}$ & $\begin{array}{c}0.000 \\
(0.000)\end{array}$ & $\begin{array}{l}0.000^{*} \\
(0.000)\end{array}$ & $\begin{array}{l}-0.000 \\
(0.000)\end{array}$ & $\begin{array}{c}0.000 \\
(0.000)\end{array}$ \\
\hline Female & $\begin{array}{c}-0.117 * * * \\
(0.003)\end{array}$ & $\begin{array}{c}-0.154 * * * \\
(0.005)\end{array}$ & $\begin{array}{c}-0.068^{* * *} \\
(0.005)\end{array}$ & $\begin{array}{c}-0.279 * * * \\
(0.006)\end{array}$ & $\begin{array}{c}-0.221 * * * \\
(0.005)\end{array}$ & $\begin{array}{c}-0.109 * * * \\
(0.009)\end{array}$ & $\begin{array}{c}-0.068^{* * * *} \\
(0.009)\end{array}$ \\
\hline Married & $\begin{array}{c}0.019 * * * \\
(0.006)\end{array}$ & $\begin{array}{c}0.009 \\
(0.012)\end{array}$ & $\begin{array}{l}-0.014 \\
(0.012)\end{array}$ & $\begin{array}{c}0.007 \\
(0.013)\end{array}$ & $\begin{array}{c}0.032 * * * \\
(0.012)\end{array}$ & $\begin{array}{l}-0.005 \\
(0.043)\end{array}$ & $\begin{array}{c}0.016 \\
(0.049)\end{array}$ \\
\hline $\begin{array}{l}\text { Education dummies } \\
\text { Country dummies } \\
\text { Wave dummies }\end{array}$ & $\begin{array}{l}\text { yes } \\
\text { yes } \\
\text { yes }\end{array}$ & $\begin{array}{l}\text { yes } \\
\text { yes } \\
\text { yes }\end{array}$ & $\begin{array}{l}\text { yes } \\
\text { yes } \\
\text { yes }\end{array}$ & $\begin{array}{l}\text { yes } \\
\text { yes } \\
\text { yes }\end{array}$ & $\begin{array}{l}\text { yes } \\
\text { yes } \\
\text { yes }\end{array}$ & $\begin{array}{l}\text { yes } \\
\text { yes } \\
\text { yes }\end{array}$ & $\begin{array}{l}\text { yes } \\
\text { yes } \\
\text { yes }\end{array}$ \\
\hline $\begin{array}{l}\text { Observations } \\
\text { R-squared }\end{array}$ & $\begin{array}{c}118,200 \\
0.234 \\
\end{array}$ & $\begin{array}{c}133,811 \\
0.086\end{array}$ & $\begin{array}{c}130,836 \\
0.092\end{array}$ & $\begin{array}{c}100,679 \\
0.203\end{array}$ & $\begin{array}{c}103,027 \\
0.123\end{array}$ & $\begin{array}{c}29,929 \\
0.169\end{array}$ & $\begin{array}{c}29,153 \\
0.190\end{array}$ \\
\hline
\end{tabular}


Table 8

Family ties and per capita GDP

\begin{tabular}{|c|c|c|c|c|}
\hline & (1) & (2) & (3) & (4) \\
\hline VARIABLES & Log GDP & Log GDP & Log GDP & Log GDP \\
\hline Family ties & $\begin{array}{c}-1.984 * * * \\
(0.383)\end{array}$ & $\begin{array}{c}-0.969 * * \\
(0.441)\end{array}$ & & \\
\hline Inherited family values & & & $\begin{array}{c}-0.860^{* *} \\
(0.428)\end{array}$ & $\begin{array}{c}-0.786^{* * *} \\
(0.285)\end{array}$ \\
\hline Log (years of schooling) & & $\begin{array}{c}2.414 * * * \\
(0.498)\end{array}$ & & $\begin{array}{c}2.350 * * * \\
(0.307)\end{array}$ \\
\hline Observations & 80 & 73 & 122 & 100 \\
\hline R-squared & 0.221 & 0.409 & 0.064 & 0.522 \\
\hline
\end{tabular}


Table 9

Family ties and regional income

\begin{tabular}{|c|c|c|c|c|c|c|c|}
\hline & $\begin{array}{c}(1) \\
\text { Whole sample }\end{array}$ & $\begin{array}{c}\text { (2) } \\
\text { Whole sample }\end{array}$ & $\begin{array}{c}\text { (3) } \\
\text { Europe }\end{array}$ & $\begin{array}{c}(4) \\
\text { Africa }\end{array}$ & $\begin{array}{l}(5) \\
\text { Asia }\end{array}$ & $\begin{array}{c}(6) \\
\text { North } \\
\text { America and } \\
\text { Oceania } \\
\end{array}$ & $\begin{array}{c}(7) \\
\text { South } \\
\text { America }\end{array}$ \\
\hline Family ties & $\begin{array}{c}-0.540^{* * * *} \\
(0.078)\end{array}$ & $\begin{array}{c}-0.349^{* * * *} \\
(0.111)\end{array}$ & $\begin{array}{c}-0.287 * * \\
(0.127)\end{array}$ & $\begin{array}{c}-1.383 * * * \\
(0.398)\end{array}$ & $\begin{array}{c}-0.498^{* *} \\
(0.201)\end{array}$ & $\begin{array}{l}-0.327 \\
(0.408)\end{array}$ & $\begin{array}{c}0.133 \\
(0.444)\end{array}$ \\
\hline $\begin{array}{l}\text { Country fixed } \\
\text { effect }\end{array}$ & no & yes & yes & yes & yes & yes & yes \\
\hline Observations & 1,197 & 1,197 & 661 & 103 & 255 & 83 & 86 \\
\hline R-squared & 0.047 & 0.526 & 0.466 & 0.691 & 0.482 & 0.731 & 0.354 \\
\hline
\end{tabular}

Table 10

Family ties and institutions

\begin{tabular}{lcccccc}
\hline \multicolumn{7}{c}{ Family ties and institutions } \\
& $\begin{array}{c}\text { Control of } \\
\text { corruption }\end{array}$ & $\begin{array}{c}\text { Government } \\
\text { effectiveness }\end{array}$ & $\begin{array}{c}\text { Political } \\
\text { stability }\end{array}$ & $\begin{array}{c}(4) \\
\text { Rule of } \\
\text { law }\end{array}$ & $\begin{array}{c}\text { Regulatory } \\
\text { quality }\end{array}$ & $\begin{array}{c}\text { Voice and } \\
\text { accountability }\end{array}$ \\
\hline Family ties & $-1.729^{* * *}$ & $-1.575^{* * *}$ & $-1.576^{* * *}$ & $-1.595^{* * *}$ & $-1.199^{* * *}$ & $-1.428^{* * *}$ \\
& $(0.308)$ & $(0.266)$ & $(0.212)$ & $(0.281)$ & $(0.239)$ & $(0.239)$ \\
& & & & & \\
Observations & 80 & 80 & 80 & 80 & 80 & 80 \\
R-squared & 0.288 & 0.292 & 0.374 & 0.291 & 0.230 & 0.288 \\
\hline \hline
\end{tabular}


Table 11

Family ties and institutions, controlling for legal origin

\begin{tabular}{|c|c|c|c|c|c|c|}
\hline & $\begin{array}{c}\text { (1) } \\
\text { Control of } \\
\text { corruption }\end{array}$ & $\begin{array}{l}\text { (2) } \\
\text { Government } \\
\text { effectiveness }\end{array}$ & $\begin{array}{l}\text { (3) } \\
\text { Political } \\
\text { stability }\end{array}$ & $\begin{array}{c}(4) \\
\text { Rule of } \\
\text { law }\end{array}$ & $\begin{array}{c}\text { (5) } \\
\text { Regulatory } \\
\text { quality }\end{array}$ & $\begin{array}{c}(6) \\
\text { Voice and } \\
\text { accountability }\end{array}$ \\
\hline Family ties & $\begin{array}{c}-1.572^{* * *} \\
(0.395)\end{array}$ & $\begin{array}{c}-1.504^{* * *} \\
(0.357)\end{array}$ & $\begin{array}{c}-1.368^{* * *} \\
(0.278)\end{array}$ & $\begin{array}{c}-1.490^{* * *} \\
(0.370)\end{array}$ & $\begin{array}{c}-1.205^{* * *} \\
(0.309)\end{array}$ & $\begin{array}{c}-1.334 * * * \\
(0.286)\end{array}$ \\
\hline Legal origin dummies & yes & Yes & yes & yes & yes & yes \\
\hline Observations & 80 & 80 & 08 & 80 & 80 & 80 \\
\hline R-squared & 0.401 & 0.375 & 0.394 & 0.379 & 0.265 & 0.308 \\
\hline
\end{tabular}


Table 12

Inherited family values and institutions

\begin{tabular}{|c|c|c|c|c|c|c|}
\hline & $\begin{array}{c}\text { (1) } \\
\text { Control of } \\
\text { corruption }\end{array}$ & $\begin{array}{l}\text { (2) } \\
\text { Government } \\
\text { effectiveness }\end{array}$ & $\begin{array}{c}(3) \\
\text { Political } \\
\text { stability } \\
\end{array}$ & $\begin{array}{c}(4) \\
\text { Rule of } \\
\text { law }\end{array}$ & $\begin{array}{c}\text { (5) } \\
\text { Regulatory } \\
\text { quality }\end{array}$ & $\begin{array}{c}(6) \\
\text { Voice and } \\
\text { accountability }\end{array}$ \\
\hline Inherited family values & $\begin{array}{c}-0.664^{* * *} \\
(0.197)\end{array}$ & $\begin{array}{c}-0.622^{* * *} \\
(0.221)\end{array}$ & $\begin{array}{c}-0.558^{* * *} \\
(0.184)\end{array}$ & $\begin{array}{c}-0.630^{* * *} \\
(0.213)\end{array}$ & $\begin{array}{c}-0.477 * * \\
(0.201)\end{array}$ & $\begin{array}{c}-0.613^{* * *} \\
(0.201)\end{array}$ \\
\hline Observations & 128 & 129 & 129 & 129 & 128 & 129 \\
\hline R-squared & 0.090 & 0.081 & 0.068 & 0.083 & 0.053 & 0.082 \\
\hline
\end{tabular}

Table 13

Inherited family values and institutions, controlling for legal origin

\begin{tabular}{|c|c|c|c|c|c|c|}
\hline & $\begin{array}{c}\text { (1) } \\
\text { Control of } \\
\text { corruption }\end{array}$ & $\begin{array}{c}\text { (2) } \\
\text { Government } \\
\text { effectiveness }\end{array}$ & $\begin{array}{c}\text { (3) } \\
\text { Political } \\
\text { stability }\end{array}$ & $\begin{array}{c}(4) \\
\text { Rule of } \\
\text { law }\end{array}$ & $\begin{array}{c}\text { (5) } \\
\text { Regulatory } \\
\text { quality }\end{array}$ & $\begin{array}{c}(6) \\
\text { Voice and } \\
\text { accountability }\end{array}$ \\
\hline Inherited family values & $\begin{array}{c}-0.529 * * * \\
(0.148)\end{array}$ & $\begin{array}{c}-0.509 * * * \\
(0.174)\end{array}$ & $\begin{array}{c}-0.529 * * * \\
(0.157)\end{array}$ & $\begin{array}{c}-0.525^{* * *} \\
(0.163)\end{array}$ & $\begin{array}{c}-0.382^{* *} \\
(0.160)\end{array}$ & $\begin{array}{c}-0.499 * * * \\
(0.164)\end{array}$ \\
\hline Legal origin & yes & yes & yes & yes & yes & yes \\
\hline Observations & 122 & 122 & 122 & 122 & 122 & 122 \\
\hline R-squared & 0.340 & 0.309 & 0.260 & 0.320 & 0.235 & 0.263 \\
\hline
\end{tabular}

Coefficients are reported with robust standard errors in brackets. ***, ** and * indicate significance at the 1, 5 and $10 \%$ levels. 
Table 14

Family ties and happiness

\begin{tabular}{|c|c|c|c|}
\hline & $\begin{array}{c}\text { (1) } \\
\text { Happiness }\end{array}$ & $\begin{array}{c}\text { (2) } \\
\text { Satisfaction } \\
\text { with life }\end{array}$ & $\begin{array}{c}(3) \\
\text { State of } \\
\text { health }\end{array}$ \\
\hline Family ties & $\begin{array}{c}0.057 * * * \\
(0.001)\end{array}$ & $\begin{array}{c}0.143^{* * *} \\
(0.005)\end{array}$ & $\begin{array}{c}0.025^{* * *} \\
(0.002)\end{array}$ \\
\hline Age & $\begin{array}{c}-0.006 * * * \\
(0.000)\end{array}$ & $\begin{array}{c}-0.027 * * * \\
(0.002)\end{array}$ & $\begin{array}{c}-0.011 * * * \\
(0.001)\end{array}$ \\
\hline Age squared & $\begin{array}{c}0.000 * * * \\
(0.000)\end{array}$ & $\begin{array}{c}0.000^{* * *} \\
(0.000)\end{array}$ & $\begin{array}{c}-0.000 * * * \\
(0.000)\end{array}$ \\
\hline Female & $\begin{array}{c}0.014 * * * \\
(0.003)\end{array}$ & $\begin{array}{c}0.033^{* * *} \\
(0.010)\end{array}$ & $\begin{array}{c}-0.114 * * * \\
(0.004)\end{array}$ \\
\hline Married & $\begin{array}{l}-0.013 \\
(0.008)\end{array}$ & $\begin{array}{c}-0.128 * * * \\
(0.026)\end{array}$ & $\begin{array}{c}-0.036^{* * *} \\
(0.010)\end{array}$ \\
\hline Education dummies & yes & yes & yes \\
\hline Country dummies & yes & yes & yes \\
\hline Wave dummies & yes & yes & yes \\
\hline Observations & 222,197 & 221,458 & 187,053 \\
\hline R-squared & 0.141 & 0.179 & 0.221 \\
\hline
\end{tabular}

